\title{
Fin modules: an evolutionary perspective on appendage disparity in basal vertebrates
}

\author{
Olivier Larouche ${ }^{1} \mathbb{D}$, Miriam L. Zelditch ${ }^{2}$ and Richard Cloutier ${ }^{1 *}$
}

\begin{abstract}
Background: Fishes are extremely speciose and also highly disparate in their fin configurations, more specifically in the number of fins present as well as their structure, shape, and size. How they achieved this remarkable disparity is difficult to explain in the absence of any comprehensive overview of the evolutionary history of fish appendages. Fin modularity could provide an explanation for both the observed disparity in fin configurations and the sequential appearance of new fins. Modularity is considered as an important prerequisite for the evolvability of living systems, enabling individual modules to be optimized without interfering with others. Similarities in developmental patterns between some of the fins already suggest that they form developmental modules during ontogeny. At a macroevolutionary scale, these developmental modules could act as evolutionary units of change and contribute to the disparity in fin configurations. This study addresses fin disparity in a phylogenetic perspective, while focusing on the presence/absence and number of each of the median and paired fins.

Results: Patterns of fin morphological disparity were assessed by mapping fin characters on a new phylogenetic supertree of fish orders. Among agnathans, disparity in fin configurations results from the sequential appearance of novel fins forming various combinations. Both median and paired fins would have appeared first as elongated ribbon-like structures, which were the precursors for more constricted appendages. Among chondrichthyans, disparity in fin configurations relates mostly to median fin losses. Among actinopterygians, fin disparity involves fin losses, the addition of novel fins (e.g., the adipose fin), and coordinated duplications of the dorsal and anal fins. Furthermore, some pairs of fins, notably the dorsal/anal and pectoral/pelvic fins, show non-independence in their character distribution, supporting expectations based on developmental and morphological evidence that these fin pairs form evolutionary modules.

Conclusions: Our results suggest that the pectoral/pelvic fins and the dorsal/anal fins form two distinct evolutionary modules, and that the latter is nested within a more inclusive median fins module. Because the modularity hypotheses that we are testing are also supported by developmental and variational data, this constitutes a striking example linking developmental, variational, and evolutionary modules.
\end{abstract}

Keywords: Fishes, Median fins, Paired fins, Morphological disparity, Phylogenetic supertree, Evolutionary modularity, Agnathans, Gnathostomes, Chondrichthyans, Osteichthyans

\footnotetext{
* Correspondence: richard_cloutier@uqar.ca

'Laboratoire de Paléontologie et de Biologie évolutive, Université du Québec

à Rimouski, Rimouski, Québec G5L 3A1, Canada

Full list of author information is available at the end of the article
} 


\section{Background}

Fishes comprise the most basal representatives of the vertebrate lineage, a paraphyletic grouping that includes an astounding $\sim 32,000$ living species [1]. Fishes display a correspondingly high level of disparity in many aspects of their body plan (Fig. 1). For centuries, it has been recognized that part of this disparity is due to the numerous fin configurations, including the number of fins, their size, their position on the body, and their types of skeletal support [2-4]. Fins can be either median (dorsal, anal, caudal, and adipose fins) or paired appendages (pectoral and pelvic fins) that are used primarily for the purpose of locomotion. Morphological disparity in fin configurations of living fishes can readily be observed when considering the presence or absence of these appendages: examples of fin losses are known for each of the median and paired fins, including the caudal fin (e.g., Mola mola). Alternatively, fins can also be duplicated or even triplicated (e.g., the dorsal fins in Gadus morhua). In some cases entirely new fins can emerge, as in the case of the adipose fin in some teleosts [5].

The evolutionary sequence leading to the origin of fish appendages has not been completely resolved yet (although a good synthesis of what is known at the molecular level is provided in [6]). It is generally acknowledged that fins first appeared as median dorsal and ventral structures during the Lower Cambrian (ca. $535 \mathrm{Ma}$ ): the oldest known vertebrate fossils display well-developed median fins but no paired fins
[7-9]. The anaspids, a group of jawless fishes, are the most primitive known vertebrates with unambiguous paired fins [10]. However, the most basal vertebrates that conclusively display endoskeletal structures and associated musculature in paired appendages are among another group of jawless fishes, the osteostracans [10-12]. The osteostracan paired fins are considered by most as homologous to the pectoral fins of jawed vertebrates (e.g., [11, 13-15]), while the pelvic fins appeared later on among stem gnathostomes [16-19]. Thus, the fossil record seemingly indicates that the pectoral fins appeared before the pelvic fins $[10,20,21]$.

One potential explanation for both the emergence of new fins and the observed disparity in fin configurations is that fins are modular. Modularity, defined most broadly, means that organisms can be decomposed into smaller components which are termed modules [22-24]. Modules are therefore discrete and internally coherent units that may develop and also evolve quasi-independently from other modules [25-27]. There are different kinds of modules that are defined according to the processes in which they are involved. Developmental modules are parts of an organism that are quasi-autonomous in their patterns of formation and differentiation [28-30], variational modules comprise traits that covary within populations [30-32], and evolutionary modules comprise traits that co-evolve $[31,33,34]$. Because of their quasi-independence, developmental modules may correspond to variational or

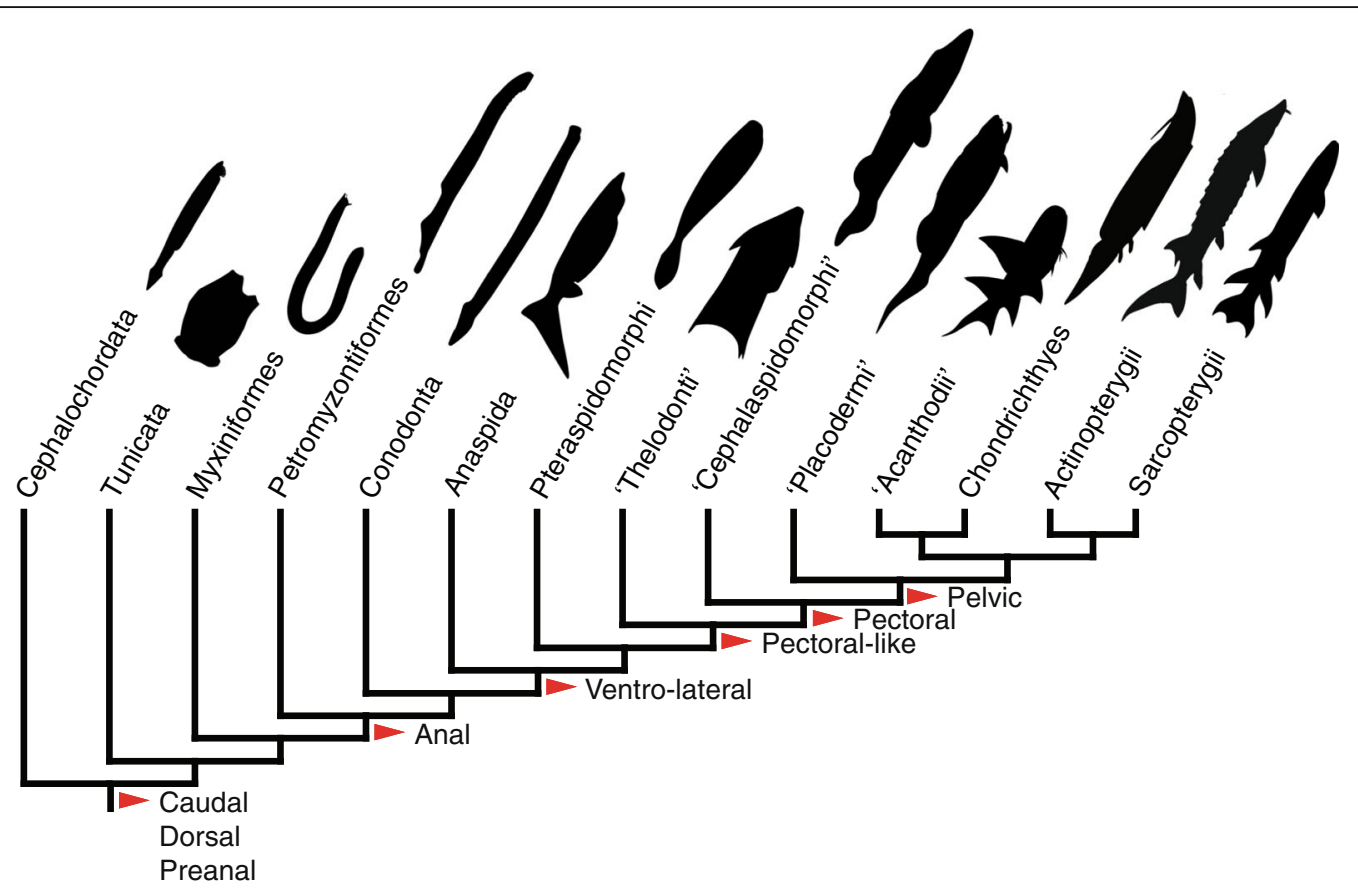

Fig. 1 A sample of the disparity in fin configurations in extant and extinct fishes. The phylogenetic framework is a simplified version of the results of the supertree analysis (Fig. 2; Additional file 1: B). Nodes where new fins are sequentially added are identified 
evolutionary modules as well $[26,34]$. Modules may also be susceptible to duplication, dissociation, divergence, and/or co-option [28]. This can lead to the repetition of individual structures that, if decoupled, can subsequently follow their own evolutionary trajectories [23, 28, 35]. Such a process of modular duplication followed by decoupling has been hypothesized to facilitate the emergence of morphological and/or functional innovations [23, 28, 36-38]. Thus, the concept of modularity is well suited to investigate the functional and developmental disparity observed in organisms [30], and it may account for the high disparity of fin configurations in fishes.

Hypotheses of modularity have already been proposed for both median and paired fins in fishes. Four fundamental modules involved in the positioning and patterning of median fins have been hypothesized for living actinopterygians (ray-finned fishes): the designated positioning modules refer to similar positions along the body axis between the dorsal and anal fins, while the designated patterning modules refer to similarities in anatomical development between these two fins [39]. Some of these patterning modules have also been identified in fossil actinopterygians and sarcopterygians (lobe-finned fishes), suggesting that they could have been inherited from a common ancestor to all osteichthyans (bony fishes, comprising all actinopterygians and sarcopterygians) [40]. Developmental evidence from the catshark (Scyliorhinus canicula) also indicates that modules might be involved in the positioning of the dorsal and anal fins in chondrichthyans (cartilaginous fishes) [41]. It has also been suggested that developmental mechanisms could have been co-opted from the median fins, leading to the emergence of the paired fins [6, 41-44]. Furthermore, most authors generally consider that the pectoral fins appeared before the pelvic fins $[10,13,17,20,21]$, leading to the hypothesis that the pelvic fins might represent a reiteration of the pectoral fins module. Duplication of a paired fins module followed by decoupling would help to explain why pectoral and pelvic fins can be altered or lost independently $[10,45,46]$.

Modularity can offer a valuable framework to investigate both the emergence of morphological disparity in fin configurations and the sequential appearance of fins in vertebrates. New fins could arise through processes such as fin module duplications that could subsequently become decoupled on an evolutionary timescale. However, two main issues complicate the interpretation of these evolutionary transformations of fins: (1) the lack of consensus regarding the homology of structures found in early vertebrate appendages [47] and (2) the lack of consensus concerning phylogenetic relationships among fishes (see, e.g., [12, 48-61]). With this in mind, this study has two principal objectives. The first is to characterize the morphological disparity in fin configurations in an evolutionary perspective, and to investigate possible scenarios for the sequential appearance of each one of the median and paired fins. This evolutionary perspective required a phylogenetic context for the analyses. Because a complete phylogeny of extinct and extant fishes at the ordinal level has not yet been published, we used a supertree approach to summarize findings from recent investigations of basal vertebrate interrelationships. The second objective is to analyze covariation patterns between fins in terms of their presence/absence at a macroevolutionary scale, which could indicate their evolutionary modularity. We predicted that fins that are hypothesized to share developmental or evolutionary modules controlling their positioning and/or patterning should also covary in their presence/ absence data.

\section{Methods}

\section{Fin presence/absence dataset \\ Taxonomic selection}

A dataset was constructed using a sample of representative species from 144 orders of fishes. Ordinal classification of extant species followed Nelson et al. [1] and Fishbase [62]. For fossil taxa, ordinal classifications of different authors have been used in relation to the taxonomic group, with some minor taxonomic modification based on the most recent literature: Janvier [16] for agnathans in general; Märss et al. [63] for thelodonts; Denison [64] and Young [65] for placoderms; Nelson et al. [1] for acanthodians; Ginter et al. [66] for elasmobranchs and Stahl [67] for holocephalians; Nelson et al. [1] for actinopterygians; and Cloutier and Ahlberg [68] for sarcopterygians. The sample comprised a total of 2730 taxa (607 extinct, 2123 extant), representing about 9\% of current estimates of fish species richness ( 32,000 living species [1]). Species were selected to maximize diversity within each one of the orders. This was done by sampling individual orders proportionately to their species richness while maximizing the number of families and genera taken into account. Special care was taken not to oversample extreme morphologies. For the fossil data, a selection was made based on the availability and completeness of morphological data. Furthermore, scoring of fin characters of fossil taxa was based mostly on photographs and on the descriptive work, and not only on published paleontological reconstructions. The inclusion of fossil taxa is important to reveal basal character states which might not be observable in more recent and derived forms.

\section{Appendage terminology}

The extensive disparity in fin morphologies and the debated homologies of some of the fins among different groups of fishes required that we come up with consistent defining criteria for each of them. We did not define the fins based on strict homology criteria in order to be able to score for the totality of the disparity encountered 
in the analysis. Patterson [69] proposed that three criteria should be used to define homologous structures: (1) similarity (topographical correspondence and ontogenetic transformation), (2) conjunction (or anatomical singularity), and (3) congruence (phylogenetic congruence with other homologies). In our case, the identity of the fins was established largely on the basis of a positional criterion, which is one of these criteria (topographical similarity) used to assess homology between structures [69]. Structural and ontogenetic criteria were also used when position alone was insufficient to clearly define some fins and when these data were available from the literature. The definitions used for the scoring of fin characters are provided in Table 1.

\section{Appendage coding}

Species considered in the analyses were scored for the presence or absence and the number of each one of the fins: dorsal fin $(0,1,2$, or 3$)$, adipose fin ( 0 or 1$)$, median ventral fin $(0$ or 1$)$, anal fin $(0,1$, or 2$)$, caudal fin (0 or 1$)$, ventrolateral paired fins (0 or 1$)$, pectoral fins (0 or 1$)$ and pelvic fins (0 or 1$)$. The scoring reflected the number of each fin present and had no implications as to the plesiomorphic or apomorphic condition of characters. Presence or absence of each of the fins was assessed based on multiple sources including specimen descriptions, photographic material, radiographs, illustrations, and paleontological reconstructions.

\section{Fish supertree}

Our investigation of fin morphological disparity required a phylogenetic framework. Yet, phylogenies of basal vertebrates have not reached a generalized consensus (see, e.g., [12, 48-61]), and a complete phylogeny of fossil and extant fishes at the ordinal level that encompasses the entire taxonomical span considered in this study is not currently available.

The phylogenetic framework was constructed using a supertree approach, more specifically with the matrix representation with parsimony (MRP) algorithm [70-72], which is the most commonly used method [73-76]. The MRP method is well suited for inferring topologies from diverse partially overlapping datasets [70-72, 77, 78], notably for the joint analysis of fossil and extant data [74, 79]. A set of 118 source trees (Additional file 1: A) was compiled. Selected source trees were required to have been generated using modern computer-based phylogenetic analyses (the analyses used were published between 1986 and September 2016) of either morphological or molecular datasets. The supertree was constructed using the phangorn package [80] in $\mathrm{R}$ version 3.2.4 [81]. Source trees were simplified at the ordinal level whenever necessary. Some fish orders continue to be used for taxonomic simplification even though they are most likely paraphyletic or polyphyletic (e.g., Climatiiformes, Perciformes, Osteolepiformes). These orders were subdivided into smaller units that could be assigned to multiple nodes in individual source trees prior to generating the consensus topology. Phylogenetic supertrees were reconstructed with the maximum parsimony function that generates a single most parsimonious solution, and with Nixon [82]'s Parsimony Ratchet that performs heuristic searches and generates a set of most parsimonious trees [80].

In order to manage the broad phylogenetic scope of the source trees, five separate supertree analyses were conducted, i.e., agnathans, basal gnathostomes (placoderms and acanthodians), chondrichthyans, actinopterygians, and

Table 1 Terminology used to define fins for the scoring of characters among taxa

\begin{tabular}{|c|c|c|}
\hline Terms used in this paper & Definition & Other terms that have been used \\
\hline Median ventral fin & $\begin{array}{l}\text { An unpaired ventral finfold that can be inserted either anteriorly } \\
\text { (e.g., some Myxiniformes) or posteriorly to the anus, and anteriorly } \\
\text { to the anal fin when it is present (e.g., some Stomiidae, } \\
\text { Paralepididae and Phallostethidae (Teleostei)) }\end{array}$ & $\begin{array}{l}\text { Preanal finfold (or skinfold), ventral } \\
\text { adipose fin }\end{array}$ \\
\hline Ventrolateral paired fins & $\begin{array}{l}\text { Ventrolaterally positioned fins or fin supports placed along the } \\
\text { trunk that are generally long-based and that are of uncertain } \\
\text { homology to the pectoral and/or pelvic fins }\end{array}$ & $\begin{array}{l}\text { Ventrolateral finfolds, intermediate spines, } \\
\text { prepelvic spines }\end{array}$ \\
\hline Pectoral fins & $\begin{array}{l}\text { Short-based paired fins inserted on the thorax close to the gill } \\
\text { openings }\end{array}$ & $\begin{array}{l}\text { Suprabranchial fins, paired flaps, pectoral } \\
\text { flaps, pectoral swimming appendages }\end{array}$ \\
\hline Pelvic fins & $\begin{array}{l}\text { Ventrally inserted short-based paired fins, always located } \\
\text { anteriorly to the anus/cloaca }\end{array}$ & Ventral fins \\
\hline Dorsal fin & $\begin{array}{l}\text { Fins located on the dorsal midline of the body, between the } \\
\text { head and the tail }\end{array}$ & \\
\hline Anal fin & $\begin{array}{l}\text { Fins located on the ventral midline between the anus } \\
\text { (or cloaca) and the tail }\end{array}$ & \\
\hline Adipose fin & $\begin{array}{l}\text { A small non-rayed fin usually located medially between } \\
\text { the dorsal and caudal fins; this median fin is present among } \\
\text { several groups of ostariophysans and basal euteleosts }\end{array}$ & Fatty fin, dorsal organ, dorsal filament \\
\hline Caudal fin & The caudal fin is located at the extremity of the tail & Tail fin \\
\hline
\end{tabular}


sarcopterygians. The interrelationships among these larger more inclusive groups are well resolved, and the resulting trees from each individual analysis were thus combined to generate the complete supertree of fishes. An exception to this concerns the interrelationships between placoderms, acanthodians, and crown gnathostomes, which are currently strongly debated. For this purpose, the supertree analysis focusing on these stem gnathostome groups incorporated chondrichthyans and osteichthyans as terminal branches.

The MRP supertree method combines source trees with the assumption that datasets are independent $[73,76,83,84]$. However, in this case some source trees cannot be considered as independent, particularly for the fossil groups where phylogenetic analyses often build upon previously published data matrices, adding or re-scoring taxa and characters. To reduce this bias, care was taken to select source trees where either the character sets or the list of taxa had been substantially modified. The impracticability of this assumption of total independence of source trees is a well-known issue in supertree constructions, and nonindependence is unlikely to be completely eliminated [74, 76, 83, 85-88].

Phylogenetic supertrees have also been criticized for losing contact with the primary data from which they are derived [84, 85, 88-91]. Bryant ([84], p. 366) added that MRP supertrees are likely to violate at least some phylogenetic principles and are consequently best considered as a "heuristic synthesis of available hierarchical information, rather than the products of rigorous phylogenetic analysis." Nonetheless, phylogenetic supertrees provide a reasonable alternative to an analysis based on total evidence in situations where such an approach is unavailable [71, 73, 74].

\section{Mapping of the fin characters on the supertree}

A summary of the presence/absence data was mapped on the supertree (Fig. 2). This was done by compiling the observed character states for individual fins within each of the orders (Additional file 2), and mapping the information on the terminal branches of the tree. This allowed us to explore possible scenarios of sequential appearance of fins, as well as to determine where most of the morphological disparity in fin configurations was concentrated in the phylogeny of fishes.

\section{Covariation in the number of fins present}

Multiple correspondence analyses were used as an exploratory method to investigate covariation among fins in the presence/absence data. Relationships between pairs of fins were also statistically tested using Fisher's exact test. Since Fisher's exact test only tells us if there is non-independence in frequencies of observations between two qualitative variables, we used Spearman's rank correlation coefficients to establish the direction of the relationships between variables. For each pair of fins, a positive correlation indicates that they tend to be jointly present or jointly absent. Alternatively, a negative correlation means that the variables have opposite trends: for instance, one fin is present while the other is absent.

As described in the previous section, prior to running the analyses, the dataset was summarized by identifying all of the unique fin combinations within individual orders. An analysis was also performed by identifying all unique combinations for the entire dataset, excluding combinations that contained missing data, resulting in 51 fin combinations. Sensitivity analyses were performed to assess the effect of missing data: this was done by running separate analyses where taxa with the most missing fin characters were sequentially removed.

Multiple correspondence analyses were performed using the ca package [92], and Spearman's rank correlations were calculated with the Hmisc package [93] in $\mathrm{R}$ version 3.2.4 [81].

\section{Results}

\section{Fish supertree}

The phylogenetic supertree analysis summarizes the topologies of 17 source trees for agnathans, 13 trees for basal gnathostomes (placoderms and acanthodians), 24 trees for chondrichthyans, 39 trees for actinopterygians, and 25 trees for sarcopterygians. The supertree generated using Nixon's Parsimony Ratchet and 50\% majority rule consensus contains 163 terminal branches and 156 internal nodes, making it $96.3 \%$ resolved compared to a fully dichotomous phylogenetic tree. The strict consensus tree contains 142 internal nodes, making it $87.6 \%$ resolved. The single most parsimonious solution using the optimum parsimony setting generated a tree with 160 internal nodes, making it $98.8 \%$ resolved. We used a pruned version of the $50 \%$ majority rule supertree (Additional file 1: B) for the mapping of fin characters (Fig. 2). The strict consensus and the optimum parsimony solutions can be found in Additional file 1: C, D.

To our knowledge, this is the first time an attempt has been made to reconcile such a large number of fish orders within a single supertree using modern phylogenetic methods. Most recently published trees with broad taxonomic scopes have focused on interrelationships among agnathans, basal gnathostomes, or derived actinopterygians (Percomorpha). The phylogenetic relationships of basal vertebrates, particularly the interrelationships of fossil taxa, have been debated for many years (Additional file 1: E). Among these contentious groups, our consensus topology, generated from recent phylogenetic analyses, 


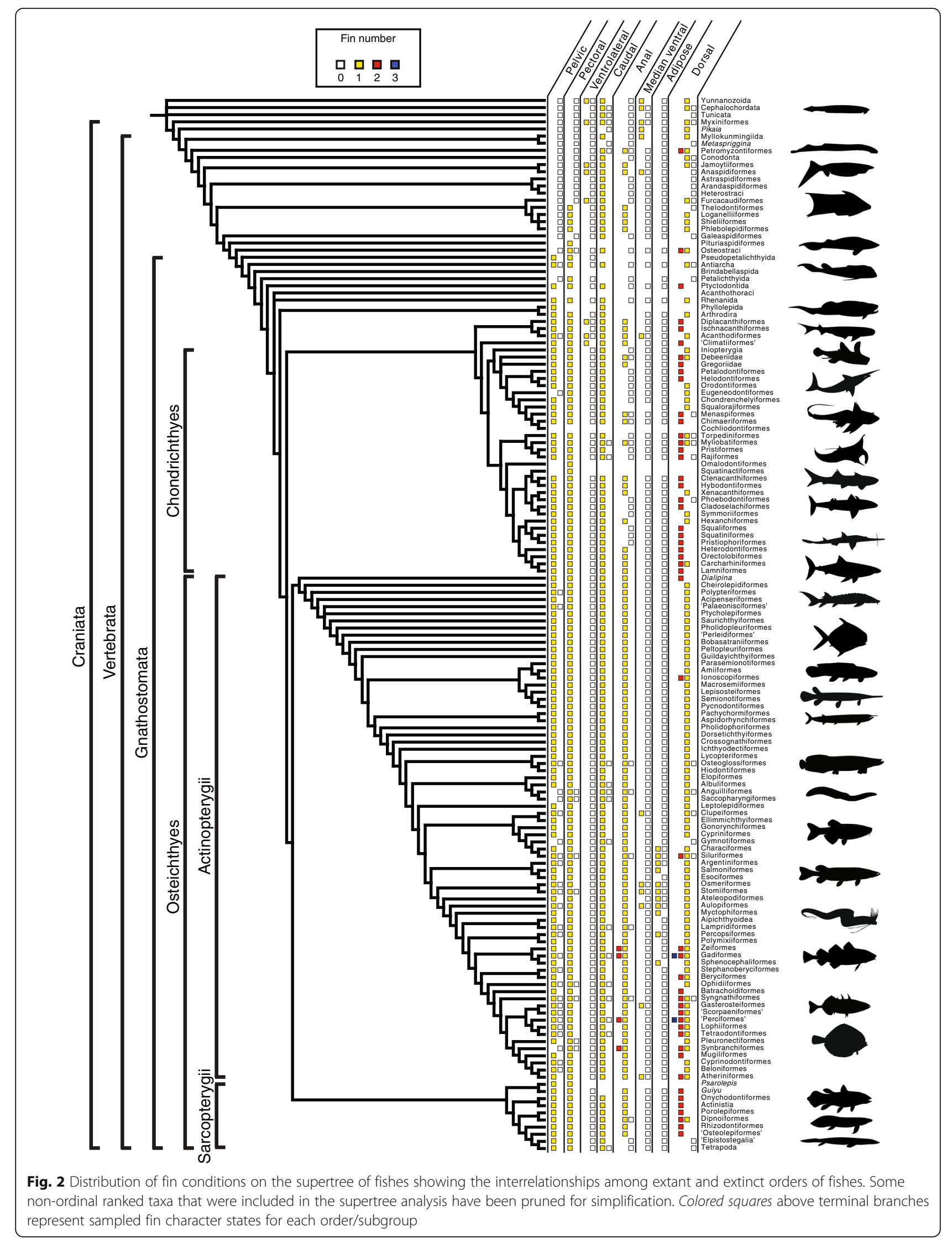


posits that living agnathans are paraphyletic, thelodonts are monophyletic, placoderms are stem gnathostomes, and acanthodians are stem chondrichthyans. As for chondrichthyans, actinopterygians, and sarcopterygians, the supertree analysis recovered most ordinal groupings that have generally been recognized as clades (e.g., Euchondrocephali, Elasmobranchii, Squalomorphii, Galeomorphii, Osteoglossomorpha, Elopomorpha, Otocephala, Acanthomorpha, Tetrapodomorpha).

\section{Mapping the evolutionary history of fish appendages}

The mapping of the presence/absence data on the supertree (Fig. 2) allows us to (1) visually establish where most of the morphological disparity occurs within the phylogeny and (2) infer the order of appearance of each of the fins. There are three sections of the phylogeny where most of the disparity in fin configurations is concentrated: (1) agnathans, (2) chondrichthyans, and (3) derived actinopterygians. The disparity in agnathans is largely due to the original diversification of fin configurations and the sequential addition of novel fins within this paraphyletic assemblage of basal fishes, while the disparity in chondrichthyans and actinopterygians results mostly from fin losses, duplications of pre-existing fins, or the addition of new fins.

\section{Agnathans}

With the exception of the pelvic and adipose fins, most fins appear early during the evolutionary history of fishes. Median fins are already present along the dorsal and ventral midline, even in the most basal craniates and vertebrates (e.g., Haikouella, Myllokunmingia, and Haikouichthys). The fin which extends along the ventral midline in these forms is positioned anteriorly to the anus and as such does not qualify as an anal fin. This fin configuration is reminiscent of what is observed in cephalochordates, although in the latter case, the dorsal finfold is comparatively longer in its anterior extent, reaching the tip of the notochord where it forms the "rostral fin." In Haikouella and Haikouichthys, the median fins are continuous around the tail, where they form a rudimentary caudal fin. A well-developed caudal fin is a generalized feature of all other agnathan taxa with the exception of a few hagfishes and lampreys. The presence of a caudal fin early in the evolutionary history of fishes is expected, considering that a postanal tail is a chordate synapomorphy: even tunicates possess a caudal fin prior to metamorphosis [94]. An anal fin is present in a few Carboniferous lampreys and is commonly found in anaspids and some thelodonts.

Paired fins also arise among agnathans. Paired fins first occur as long-based ribbon-like fins with parallel support structures, such as in anaspids. In osteostracans and some thelodonts, the paired fins are shorter-based and have a position comparable to that of pectoral fins. However, although homology of the osteostracan paired fins to the gnathostome pectoral fins has been a generalized view for many years, most authors remain conservative in such an interpretation for the thelodont paired fins. Indeed, many authors acknowledge the similarity in positioning but avoid making a statement of homology by referring to these fins as "pectoral-level fins," "pectoral appendages," or as "suprabranchial fins" (see, e.g., $[11,47,50,95-98])$.

The disparity in fin configurations within agnathans is predominantly due to differences among taxa as to the presence or absence of the median and paired fins as they successively appear during the evolutionary history of these early fishes, generating novel combinations in different groups. A few taxa also possess two dorsal fins, a condition that seems to have evolved independently in lampreys and osteostracans. Based on the number of character changes on the supertree, the presence/absence of the dorsal and anal fins seem to be the most important source of disparity in fin configurations in agnathans, followed by the median ventral fin and ventrolateral paired fins.

\section{Chondrichthyans}

In chondrichthyans, some fins contribute very little to the disparity in fin configurations: the pectoral fins are always present, the pelvic fins are lost only in the Eugeneodontiformes, and the caudal fin is always present, except in Myliobatiformes, where it is generally absent, and in Rajiformes, where it is occasionally absent. Most of the disparity in fin configurations relates to the dorsal and anal fins. The majority of chondrichthyans have one or two dorsal fins, although some forms are characterized by the absence of this fin (e.g., some Rajiformes, Torpediniformes, and Myliobatiformes). Absence of the anal fin is much more frequent than that of the dorsal fin, particularly among batoids, squalomorphs, and holocephalans: the anal fin is lacking in at least some representatives of 18 chondrichthyan orders, whereas the dorsal fin is lacking in some representatives of only five orders.

\section{Actinopterygians}

Basal actinopterygians show very little disparity in their fin configurations: they generally have single dorsal, anal, and caudal fins, and paired pectoral fins. The only source of disparity concerns the occasional loss of the pelvic fins and the presence of two dorsal fins in Dialipina salgueiroensis [99] and Placidichthys bidorsalis [100]. The second dorsal fin in Dialipina supports the hypothesis that the plesiomorphic condition for basal gnathostomes might have been the presence of two 
dorsal fins $[16,99,101,102]$, whereas the presence of two dorsal fins in Placidichthys is secondarily derived.

In contrast, derived actinopterygians are much more disparate in their fin configurations. Part of this disparity can be accounted for by repeated losses of some of the fins. Indeed, any of the median and paired fins, including the caudal fin, can be lacking in some actinopterygian groups. The pelvic fins are the most frequently lost: they are reported as absent in representatives of 26 orders from our dataset. Comparatively, only 11 orders contain species that lack a caudal fin, eight orders contain species that lack pectoral fins, six orders contain species that lack the dorsal fin, and five orders contain species that lack an anal fin. The disparity among derived actinopterygians can also be explained partly by apparent duplications of the median fins. Derived actinopterygians, more specifically the Acanthomorpha, frequently possess more than one dorsal and/or anal fin: 13 actinopterygian orders contain species that have at least two separate dorsal fins, and four of these orders contain species that also have two anal fins. Furthermore, some species of two acanthomorph orders even show three separate dorsal fins. Yet another source of disparity in actinopterygians is brought about by the addition of novel fins. The adipose fin is considered as such an evolutionary novelty $[5,103]$ which first appears among the Ostariophysi. An adipose fin is present in representatives of 11 actinopterygian orders from our dataset. In some of these groups, it is occasionally combined with a median ventral fin positioned anteriorly to the anal fin (referred to as a ventral adipose fin in morphological descriptions), although this ventral fin can be present even if the dorsal adipose fin is absent. A median ventral fin is found in some species of six of the orders sampled in our actinopterygian dataset.

\section{Sarcopterygians}

Sarcopterygians display far less disparity in their fin configurations: differences among taxa are limited to the number of dorsal fins and the presence/absence of the dorsal, anal, and caudal fins. Furthermore, only two orders (Dipnoiformes and "Elpistostegalia") show some disparity in fin configurations among the species they contain. Most sarcopterygians have two dorsal fins, a single anal fin, a caudal fin, and paired pectoral and pelvic fins. The Dipnoiformes are the most disparate order in terms of fin configurations: there can be either one or two dorsal fins, and a separate anal fin is lost in derived dipnoans. Elpistostegalians, the most derived piscine tetrapodomorphs, are characterized by the loss of the dorsal and anal fins, although the caudal fin remains. The paired fins are conserved in all sarcopterygian taxa, including tetrapods where they evolved towards the forelimbs and hindlimbs [10, 16, 17, 45, 104-108].
Covariation in the presence/absence of fish appendages Multiple correspondence analyses were performed with the complete dataset (147 orders) and also on six subsets of the data corresponding to major taxonomic groups (i.e., agnathans (18 orders), total group chondrichthyans (37 orders), undoubted chondrichthyans (excluding acanthodian-like taxa; 33 orders), actinopterygians (73 orders), and sarcopterygians (7 orders)), most of which are monophyletic with the exception of agnathans. We found that the removal of taxa with missing data was for the most part inconsequential, affecting only the percentage of variance explained by the major axes of variation. As such, we focus on the results incorporating the entire dataset (Fig. 3). We limited our analysis to the first two dimensions of the MCAs because additional dimensions showed increasingly rare fin combinations in the dataset and were not biologically interpretable.

The first two dimensions of the MCA on the entire dataset (Fig. 3a) explain 21.3 and $12.8 \%$ of the variation, respectively. The first dimension contrasts fishes bearing only median ventral fins and/or ventrolateral paired fins, to fishes that have two or three dorsal and anal fins, or an adipose fin. This can be interpreted as contrasting patterns of fin configurations found in basal agnathans to those of acanthomorphs. The second dimension contrasts fishes bearing an adipose fin and a median ventral fin to those that have two (or three) dorsal and anal fins. An adipose fin is commonly found in a number of orders of basal euteleosteans, whereas the presence of three dorsal fins and two anal fins is only found in the more advanced euteleosteans (Acanthomorpha). Additionally, based on the acute angles between some vectors and similarities in their relative lengths, there is evidence for coordinated losses or duplications between some of the fins. This is observed for the coordinated duplications (or triplications) of the dorsal and anal fins, as well as for the coordinated losses of the dorsal and anal fins, and of the pectoral and pelvic fins.

The first two dimensions of the MCA on agnathans (Fig. 3b) explain 25.1 and $19.6 \%$ of the variation, respectively. The first dimension contrasts fishes that have caudal, dorsal, anal, and pectoral fins to those that do not have these fins. The former pattern is characteristic of fishes close to the agnathan-gnathostome transition, such as osteostracans, while the latter fin configuration is found in the more basal agnathans that have long-based ribbonlike median and paired fins. The second dimension contrasts primarily a morphology where most fins are absent with the exception of two dorsal fins, a pattern found in a single petromyzontid fossil species, to forms where there is a single copy of each fin. The angles between the vectors for each of the fins are relatively equal, resulting in a starshaped pattern: this suggests that there is little covariation among the fins and that they are all independent from one 

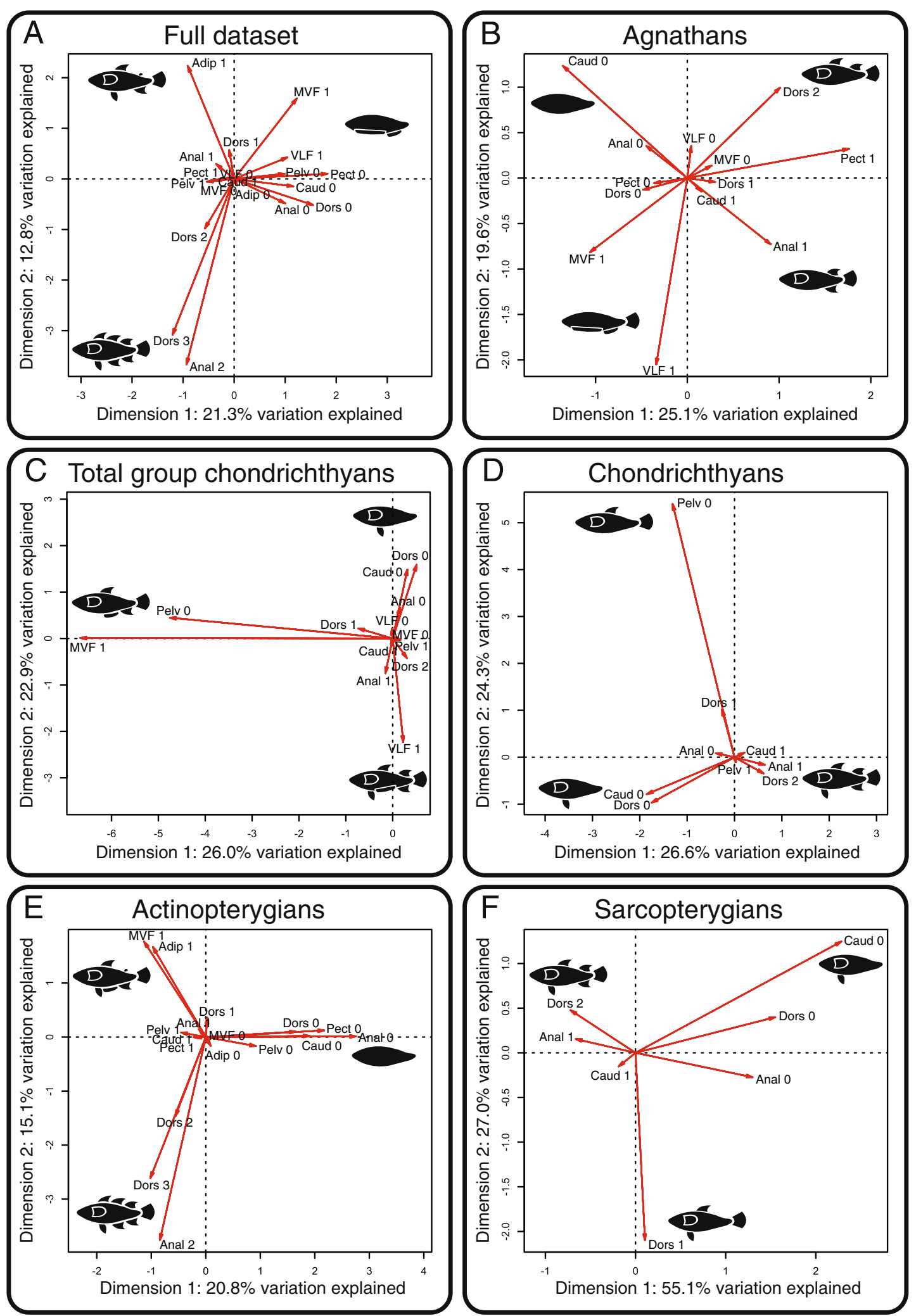

Fig. 3 Biplots of the multiple correspondence analyses. Lettered panels represent the results for a the entire dataset, $\mathbf{b}$ agnathans, $\mathbf{c}$ total group chondrichthyans, $\mathbf{d}$ chondrichthyans, e actinopterygians, and $\mathbf{f}$ sarcopterygians. Fish silhouettes represent the major trends in fin configurations among each group 
another. Alternatively, this star-shaped pattern could also partly result from the difficulties in correctly identifying homologies in fin characters among agnathans. It has been suggested, for example, that the paired fins of some anaspids and thelodonts could be homologous to the pelvic fins of gnathostomes [109].

For the total group chondrichthyans (i.e., including acanthodians and putative chondrichthyans) (Fig. 3c), the first two dimensions of the MCA explain 26.0 and $22.9 \%$ of the variation, respectively. The first dimension contrasts forms that have a single dorsal fin, no pelvic fins, and a median ventral fin, to fishes that have lost their median fins and/or have two dorsal fins. This can be interpreted as opposing the morphology of a single genus of acanthodians, Acanthodes, to the disparity in batoid morphologies. The second dimension opposes forms that have ventrolateral paired fins, an anal fin, and two dorsal fins, to forms that have lost their median fins. This opposes a morphology found in climatiid and diplacanthid acanthodians to the loss of median fins found in some batoids, more specifically among the Rajiformes and Myliobatiformes. As with the analysis on the full dataset, the relative lengths and angles between some of the vectors show coordinated patterns between some of the fins, in this case suggesting coordinated losses of the dorsal, anal, and caudal fins.

In the analysis restricted to undoubted chondrichthyans (Fig. 3d), the first two dimensions of the MCA explain $26.6 \%$ and $24.3 \%$ of the variation, respectively. The first dimension contrasts forms that have lost most of their median fins and the pelvic fins, to morphologies where all of the fins are present including two dorsal fins. The latter pattern is characteristic of the nonbatoid neoselachians (Galeomorphii and Squalomorphii), while the former seems to be a combination of characters found either in batoids or in the Eugeneodontiformes. The second axis primarily contrasts forms that have lost the pelvic fins and have a single dorsal fin to those that have lost the dorsal and caudal fins or have two dorsal fins. As such, this dimension of the MCA opposes the Eugeneodontiformes, the only chondrichthyan taxon where the pelvic fins are absent, to the disparity patterns of other chondrichhyans.

In actinopterygians, the first two dimensions of the MCA (Fig. 3e) explain 20.8 and $15.1 \%$ of the total variation, respectively. The first dimension contrasts forms that have lost all of their fins to morphologies with additional fins. These accessory fins correspond either to the addition of second and third dorsal and anal fins, or to the addition of median ventral fins and adipose fins. The loss of all fins is rare and can be found only in a few Anguilliformes and Gasterosteiformes, generally associated with an elongated body shape. The pattern with supplementary fins is characteristic of the more advanced teleosteans (Ostariophysi and Euteleostei). The second dimension opposes forms where a median ventral fin and an adipose fin are present to forms with serial duplications of the dorsal and anal fins. This contrasts two ways by which additional median fins can be added to the body; the first is characteristic of basal euteleosts, while the latter is characteristic of the acanthomorphs. As with the analysis focusing on the full dataset, the angles and lengths of the vectors suggest coordinated patterns of loss and duplication among fins. Again, the presence of additional dorsal and anal fins appears coordinated. The presence of a median ventral fin and of an adipose fin also seems to be coordinated. However, as opposed to the results from the full dataset, here the acute angles between vectors representing fin losses suggest coordinated losses that affect all median and paired fins at once.

In sarcopterygians, the first two dimensions of the MCA (Fig. 3f) explain 55.1 and $27.0 \%$ of the variation, respectively. The disparity in fin configurations is limited to the number of dorsal fins and the presence/absence of the dorsal, anal, and caudal fins. Pectoral and pelvic fins are always present in sarcopterygians. The first axis contrasts fishes bearing a caudal, an anal, and two dorsal fins to forms that have lost all of their median fins. Essentially, this contrasts most piscine sarcopterygians to tetrapods. The second axis contrasts forms that have a single dorsal fin and no anal fin to forms that have either two dorsal fins, or where the dorsal and the caudal fins are both absent. This contrasts the derived condition found in dipnoans to a combination of fin characters that is a composite of the other sarcopterygians. As opposed to the results for most of the other analyses, the angles and relative lengths of the vectors from this analysis do not suggest any particularly strong relationships between any of the variables.

MCAs were also performed for the complete gnathostome dataset (125 orders) and the complete osteichthyan dataset (80 orders) (Additional file 3: A-C). The overwhelming actinopterygian pattern was pervasive in both of these analyses, particularly for the osteichthyan dataset. This is not unexpected, since the ordinal diversity and morphological disparity in actinopterygians by far exceed that of the other gnathostome groups.

Fisher's exact test was used to identify sets of fins that display non-random patterns in their presence/absence, which would be congruent with a modular organization. In other words, if two fins are part of the same fin module, we expect that coordination in their character states (presence, absence, or duplication) should be more frequently observed. Spearman's rank correlation was used to determine if the significant relationships between pairs of fins revealed by Fisher's exact test is due to covariation in the presence/absence data, or from antagonistic relationships 
(one fin is present while the other is absent). In the analysis where unique fin combinations were identified for each individual order, a number of pairs of fins showed non-random patterns in their co-occurrence (Tables 2 and 3 ). Highly significant results were obtained for the following fin pairs using Fisher's exact test: median ventral/pectoral, ventrolateral paired/pectoral, pectoral/pelvic, pectoral/dorsal, pectoral/anal, pectoral/caudal, pelvic/dorsal, pelvic/adipose, pelvic/anal, pelvic/caudal, and dorsal/ anal fins. All of these pairs of fins were shown to be concurrently present or absent, with the exception of the median ventral/pectoral and the ventrolateral paired/pectoral fins, which display opposite trends in their presence/absence data. Significant results were obtained for the median ventral/ventrolateral paired, median ventral/pelvic, dorsal/adipose, dorsal/caudal, anal/adipose, and anal/caudal fins. The median ventral/ventrolateral paired, dorsal/ caudal, anal/adipose, and anal/caudal fins co-occur or are jointly absent, whereas the median ventral/pelvic, ventrolateral paired/pectoral, and dorsal/adipose fins vary in opposite directions.

The simplification of the dataset to identify every possible fin combination resulted in 51 unique combinations out of a total of 768 possibilities. Fisher's exact test (Table 4) identified a single pair of fins, the pectoral/pelvic fins, as highly statistically significant $(P=2.16 \mathrm{e}-05)$. The pectoral and pelvic fins were shown to be concurrent in their presence or absence by the results of Spearman's rank correlations (Table 5). Using this dataset, the dorsal/anal fins pair was not found to be statistically significant $(P=0.140)$. Both the pectoral/ventrolateral paired fins $(P=0.082)$ and the pelvic/adipose fins $(P=$ $0.085)$ are marginally non-significant statistically. Based on Spearman's rank correlations, the pectoral and ventrolateral paired fins were found to vary in opposite directions, whereas the pelvic and adipose fins showed coordination in their presence/absence.

\section{Discussion}

For the first time, we have an integrative picture of the evolution of fin configurations and covariation patterns of these appendages among a large diversity of lower vertebrates. The two objectives of this paper were (1) to examine the morphological disparity in fin configurations among basal vertebrates and gain insight into the sequential appearance of median and paired fins in fishes, and (2) to investigate macroevolutionary patterns of cooccurrence among some of the fins, which could then be interpreted as evolutionary modules. These two objectives are not independent. The evolutionary emergence of novel fins could involve the duplication or co-option of preexisting fin modules. Such scenarios have already been proposed, whether or not explicitly, in the context of the evolution of paired fins in early vertebrates $[6,41]$, the pectoral and pelvic fins in gnathostomes [17], the spinebrush-complex in symmoriiform sharks [110], the adipose fin in euteleosts $[5,103,111]$, and the spinous dorsal fin in acanthomorphs [39]. Modularity also promotes functional and morphological disparity, because modules can be individually optimized without affecting other parts of an organism $[22,32,112,113]$. Thus, a modular organization of appendages is useful to explain the disparity of fin configurations in fishes, but also at a larger scale of limbs in all vertebrates. The paired appendages of tetrapods provide a very telling example: the fore- and hindlimbs can be modified independently, which was a necessary prerequisite for the evolution of specialized structures, such as the wings in birds or bats $[17,46]$.

\section{Disparity in fin configurations}

The mapping of fin characters on the supertree reveals which groups are the most disparate in their fin configurations: agnathans, chondrichthyans, and derived actinopterygians display the greatest disparity in fin configurations, although they differ as to which fins are responsible for generating this disparity. Among agnathans, new fins are sequentially added and long ribbon-like fins are gradually modified into more spatially constricted median and paired fins. Thus, the disparity in this part of the tree seemingly results from tinkering with fin configurations and building towards the gnathostome Baüplan. In chondrichthyans, the most important source of disparity is the loss of some (occasionally all) of the median fins. The most disparate fin combinations are found among

Table $2 P$ values of Fisher's exact test between fins

\begin{tabular}{|c|c|c|c|c|c|c|c|}
\hline & Median ventral fin & Ventrolateral paired fins & Pectoral fins & Pelvic fins & Dorsal fins & Adipose fin & Anal fins \\
\hline Ventrolateral paired fins & 0.022 & & & & & & \\
\hline Pectoral fins & $4.53 \mathrm{e}-04$ & 0.007 & & & & & \\
\hline Pelvic fins & 0.016 & 0.354 & $2.2 \mathrm{e}-16$ & & & & \\
\hline Dorsal fins & 0.235 & 0.255 & $3.50 \mathrm{e}-09$ & $9.41 \mathrm{e}-08$ & & & \\
\hline Adipose fin & 0.052 & 1 & 0.083 & 0.002 & 0.036 & & \\
\hline Anal fins & 0.172 & 1 & $7.94 \mathrm{e}-09$ & 0.005 & $2.01 e-12$ & 0.021 & \\
\hline Caudal fin & 1 & 0.607 & 0.007 & $2.00 \mathrm{e}-04$ & 0.013 & 0.382 & 0.011 \\
\hline
\end{tabular}

The dataset comprises all possible fin configurations for each order and includes rows with missing data 
Table 3 Spearman's rank correlation coefficients between fins (below diagonal) and associated $P$ values (above diagonal)

\begin{tabular}{|c|c|c|c|c|c|c|c|c|}
\hline & Median ventral fin & Ventrolateral paired fins & Pectoral fins & Pelvic fins & Dorsal fins & Adipose fin & Anal fins & Caudal fin \\
\hline Median ventral fin & & 0.002 & $<0.0001$ & 0.008 & 0.087 & 0.019 & 0.047 & 0.583 \\
\hline Ventrolateral paired fins & 0.18 & & 0.002 & 0.265 & 0.942 & 0.451 & 0.957 & 0.271 \\
\hline Pectoral fins & -0.24 & -0.18 & & $<0.0001$ & $<0.0001$ & 0.071 & $<0.0001$ & 0.002 \\
\hline Pelvic fins & -0.16 & -0.07 & 0.57 & & $<0.0001$ & 0.003 & 0.002 & $<0.0001$ \\
\hline Dorsal fins & -0.10 & 0.00 & 0.36 & 0.34 & & 0.194 & $<0.0001$ & 0.001 \\
\hline Adipose fin & 0.14 & -0.04 & 0.11 & 0.17 & -0.08 & & 0.027 & 0.171 \\
\hline Anal fins & -0.12 & 0.00 & 0.37 & 0.18 & 0.28 & 0.13 & & 0.002 \\
\hline Caudal fin & 0.03 & 0.07 & 0.18 & 0.23 & 0.19 & 0.08 & 0.19 & \\
\hline
\end{tabular}

The dataset comprises all possible fin configurations for each order and includes rows with missing data. Sample sizes vary between 281 and 293 among pairwise comparisons because of missing data. Significant results are in boldface

teleosteans, owing to frequent losses affecting median and/or paired fins, additions of novel fins, or duplications of pre-existing fins.

In agnathans, all of the fins (with the exception of the adipose and pelvic fins that are absent) participate in the observed patterns of disparity in fin configurations. Much of this disparity can be accounted for by the gradual modification of long-based median and paired finfolds into shorter-based dorsal, anal, and pectoral fins. By gradual modifications, we mean that it is seemingly a period where the morphospace is explored, resulting in various combinations of shorter- and longer-based median and paired fins. For instance, shorter-based paired fins appear to have evolved multiple times independently (e.g., Rhyncholepis and Kerreralepis among birkeniid anaspids; Lanarkia, Phlebolepis, Turinia, and Shielia among thelodonts) before the emergence of true pectoral fins as can be found among osteostracans. Absence of the caudal fin also stands out as a source of disparity, yet this is restricted to a few species of hagfishes and lampreys. Among these, two extinct species, the putative hagfish Gilpichthys greenei and the putative lamprey Pipiscius zangerli, might in fact represent larval organisms $[114,115]$. As such, the specimens assigned to these two taxa might not represent adult morphologies, and the scoring of characters could have differed in metamorphosed specimens. In extant species, the caudal fin is generally present, although it can be vestigial or even absent (e.g., Myxine formosana [116, 117]). As for the paired fins, ventrolateral paired fins are variably present among anaspids and thelodonts, while shorterbased paired fins that have a position reminiscent of gnathostome pectoral fins are found in some thelodonts and in the osteostracans.

The disparity in fin configurations that is apparent in the chondrichthyan part of the phylogeny can appear surprising given only the modern forms. Paleozoic chondrichthyans, however, present highly disparate morphologies, comparatively making modern holocephalans and elasmobranchs seem conservative [67, 118-121]. Most of the disparity in fin configurations for chondrichthyans can be accounted for by changes in the number of median fins that are present. The anal fin is lost in representatives of numerous chondrichthyan orders. In contrast, the dorsal fin is lacking only in a few chondrichthyan taxa. Most chondrichthyans have two dorsal fins, although the presence of a single dorsal fin is common. There is also some disparity due to the occasional loss of the caudal fin in some batoids. Batoids are characterized by dorso-ventrally flattened bodies, greatly enlarged pectoral fins, and in many species, a long whiplike tail. Propulsion in most of these forms is achieved through undulations (e.g., most skates and sting rays) or oscillations (e.g., eagle rays) of the widened pectoral fins [122-124], which provides a functional context for the loss of the caudal fin when compared to most other

Table $4 P$ values of Fisher's exact test between types of fins

\begin{tabular}{|c|c|c|c|c|c|c|c|}
\hline & Median ventral fin & Ventrolateral paired fins & Pectoral fins & Pelvic fins & Dorsal fins & Adipose fin & Anal fins \\
\hline Ventrolateral paired fins & 0.592 & & & & & & \\
\hline Pectoral fins & 0.249 & 0.082 & & & & & \\
\hline Pelvic fins & 0.488 & 0.436 & $2.16 \mathrm{e}-05$ & & & & \\
\hline Dorsal fins & 0.762 & 0.828 & 0.300 & 0.259 & & & \\
\hline Adipose fin & 0.449 & 1 & 0.544 & 0.085 & 0.810 & & \\
\hline Anal fins & 1 & 0.798 & 0.142 & 0.206 & 0.140 & 0382 & \\
\hline Caudal fin & 0.417 & 0.170 & 0.750 & 1 & 0.775 & 0.561 & 0.430 \\
\hline
\end{tabular}

The dataset comprises each unique combination of character states within the entire dataset. Rows with missing data were excluded 
Table 5 Spearman's rank correlation coefficients between types of fins (below diagonal) and associated $P$ values (above diagonal)

\begin{tabular}{|c|c|c|c|c|c|c|c|c|}
\hline & Median ventral fin & Ventrolateral paired fins & Pectoral fins & Pelvic fins & Dorsal fins & Adipose fin & Anal fins & Caudal fin \\
\hline Median ventral fin & & 0.425 & 0.168 & 0.445 & 0.376 & 0.473 & 0.589 & 0.285 \\
\hline Ventrolateral paired fins & 0.11 & & 0.032 & 0.354 & 0.312 & 0.486 & 0.724 & 0.099 \\
\hline Pectoral fins & -0.20 & -0.30 & & $<0.0001$ & 0.069 & 0.195 & 0.050 & 0.700 \\
\hline Pelvic fins & -0.11 & -0.13 & 0.59 & & 0.083 & 0.050 & 0.076 & 0.931 \\
\hline Dorsal fins & -0.13 & -0.14 & 0.26 & 0.25 & & 0.474 & 0.095 & 0.446 \\
\hline Adipose fin & 0.10 & -0.10 & 0.18 & 0.28 & -0.10 & & 0.250 & 0.306 \\
\hline Anal fins & -0.08 & 0.05 & 0.28 & 0.25 & 0.24 & 0.16 & & 0.160 \\
\hline Caudal fin & 0.15 & 0.23 & -0.06 & -0.01 & 0.11 & 0.15 & 0.20 & \\
\hline
\end{tabular}

The dataset comprises each unique combination of character states within the entire dataset. Rows with missing data were excluded $(N=51)$. Significant results are in boldface

chondrichthyans that use a caudal fin-based propulsion. The paired fins do not account for much of the disparity in fin configurations: absence of the pelvic fins is limited to representatives of a single order of extinct chondrichthyans, the Eugeneodontiformes.

In derived actinopterygians, an important part of the disparity in fin configurations relates to the presence/absence of the pelvic fins and to the number of dorsal fins. Pectoral fins are lost far less frequently than the pelvic fins. For instance in teleosteans, the loss of pelvic fins has been reported in more than 100 families belonging to 20 different orders [125], whereas the loss of pectoral fins is reported for only eight teleostean orders in our dataset. The more frequent loss of the pelvic fins could reflect their lesser functional importance for swimming, when compared to the pectoral fins [125-128]. Although this study used a chondrichthyan model, experiments on fin amputations performed on the smooth dogfish (Mustelus canis) had shown that the sharks were able to correct for the loss of the pelvic fins using their median and pectoral fins [127]. In contrast, Standen [129] showed that in the rainbow trout (Oncorhynchus mykiss), the pelvic fins accomplished complex motions, indicating that their functional importance might have been underestimated. From an eco-morphological perspective, loss of the pelvic fins is often seen in fishes that possess an elongated body shape and occupy complex habitats such as coral reefs or crevices [125, 130, 131]. In these elongated fishes, the pectoral fins are often reduced as well, while the median fins are expanded in length and confluent with the caudal fin [131]. In tetrapods, limb reduction and body elongation are often associated with fossorial or semi-fossorial organisms [132-134]. Thus, in structure-rich habitats, the presence of paired lateral appendages could be disadvantageous, particularly for burrowers or parasitic fishes [135]. Additionally, some of these elongated fishes use anguilliform locomotion, which involves undulations along the entire body length and less emphasis on the use of the paired fins for propulsion $[128,136]$. From a macroevolutionary perspective, another hypothesis to explain that the pelvic fins are more frequently lost than the pectoral fins is that pelvic fins appeared after the pectoral fins during the evolutionary history of fishes [11,20], although an alternative hypothesis has been proposed whereby the pelvic fins appeared first among the anaspids [109]. Additionally, from a developmental perspective, pectoral fins develop prior to the pelvic fins [137, 138], and it has been observed that structures that develop last also tend to be the first to be lost through pedomorphosis [139]. For instance, in reptiles and lissamphibians, patterns of limb reduction reflect developmental sequences: the digits that develop last are the first to be lost in species with reduced limbs [105, 132].

The pelvic fins are frequently lost independently from the pectoral fins: this is observed in at least some representatives of two placoderm orders, one chondrichthyan order and 26 actinopterygian orders. The converse is rare, however. Among piscine gnathostomes, pectoral fin loss is restricted to actinopterygian taxa, and in seven of the eight orders where the pectoral fins are occasionally lost, the pelvic fins also tend to be absent. In fact, the loss of pectoral fins independently from the pelvic fins is only observed in some Stomiidae (Stomiiformes) and Pleuronectiformes. In stomiiform genera where this condition is observed, pectoral fins are present in larvae but are subsequently lost in juveniles and adults [140-145]. In Pleuronectiformes, some species lose their pectoral fins on a single side, while other species lose their pectoral fins on both sides; as with Stomiiformes, this loss takes place during larval metamorphosis [146]. This suggests that loss of the pectoral and loss of the pelvic fins are not entirely independent, which would be an expectation for a paired fins evolutionary module.

The dorsal fin is also responsible for a large part of the disparity in fin configuration in derived actinopterygians: there can be one, two, or three separate dorsal fins, and it can also be entirely absent. There is usually a single anal fin, but it can also be lost, and there can occasionally be two anal fins. Similarly to the paired fins, there is 
evidence for non-independence in the dorsal/anal fin characters: in orders containing species with two anal fins, two or three dorsal fins tend to be present. Another source of disparity in median fin configurations is the adipose fin which is present in many derived actinopterygians. None of the ostariophysan or euteleostan species that have an adipose fin have second (or third) dorsal fins: instead, they generally have a single centrally placed dorsal fin and a posteriorly located anal fin [147]. Conversely, groups that are close relatives but lack an adipose fin tend to have a "fast-start" morphology with posteriorly placed dorsal and anal fins $[147,148]$.

\section{Evolutionary history of fish appendages Median fins}

Median fins are present even in the earliest vertebrates. The most basal agnathan fishes are equipped with fairly well-developed median fins which include, in most cases, a caudal fin and elongated dorsal and ventral fins. For instance, the median ventral finfolds of myllokunmingiids span almost the full length of their bodies, as do their long sail-like dorsal fins [7-9, 149]. Myxiniformes also often possess long median ventral finfolds, which although sometimes interrupted around the cloaca, are continuous with the caudal fin. These elongated median fins are reminiscent of the median larval finfold observed during the early ontogeny of more advanced fishes [150, 151]. They are also reminiscent of the extensive dorsal and ventral finfolds found in the more basal cephalochordates, which are continuous around the tail, but also around the anterior tip of the notochord [152-154]. The median fins of cephalochordates are further described as being continuous with one of the two paired metapleural folds, but the latter can hardly be considered as fins because they are hollow structures filled with fluid $[155,156]$.

Even the most basal agnathans have a caudal fin. A caudal fin is absent, however, in Gilpichthys greenei and Pipiscius zangerli, two Carboniferous fossil fishes. Although these two taxa display clearly chordate characters, their assignment respectively to the Myxiniformes and Petromyzontiformes remains tentative, and both have been interpreted as possible larval organisms [115]. Thus, the absence of a caudal fin could reflect a larval condition. It is also possible that the apparent lack of a caudal fin is merely a taphonomic artifact. This could arguably be the case for Pipiscius, which presents a very posteriorly positioned dorsal fin that could certainly be interpreted as a dorsal extension of the caudal fin. Furthermore, only ten specimens were used for the original description [115]. This explanation is however less likely for Gilpichthys, its original description being based on more than 100 specimens [115]. Additionally, traces of the eyes, otic capsules, branchial pouches, and gut have been identified in both species, and these structures were shown to be less decayresistant than the caudal fin $[157,158]$.

In more advanced agnathans, a long-based preanal finfold is generally absent. Instead, many taxa possess a shorter-based and more posteriorly positioned anal fin. An anal fin is present in all anaspids that are sufficiently known from their postcranial anatomy. Furthermore, a preanal fin and an anal fin never co-occur in agnathans, with the possible exception of two birkeniid anaspids for which a few spines and an anal plate located anteriorly to the anus [159-161] were provisionally interpreted as evidence for a median ventral fin. Most modern hagfishes and lampreys lack an anal fin. However, the presence of a true anal fin has been observed in a few specimens of Petromyzon marinus [162, 163] and of Lampetra planeri [164], a phenomenon that has been interpreted as a possible atavism [165, 166]. Anal fins have also been described in two Carboniferous lampreys, Hardistiella montanensis [167] and Mayomyzon pieckoensis [168]. Based on this evidence, Forey [169] suggested that the absence of an anal fin could be a synapomorphy of recent lampreys. Additionally, the Late Carboniferous hagfish Myxinikela siroka is described as having dorsal and ventral fins (= anal fin?) that are continuous with the caudal fin, as in Mayomyzon, although in his original description, Bardack [170] raised the possibility that Myxinikela might be a juvenile. Myxinikela, Hardistiella, and Mayomyzon represent some of the oldest Myxiniformes and Petromyzontiformes for which complete non-larval specimens are known and, combined with the atavistic reappearance of an anal fin in $P$. marinus and $L$. planeri, this suggests that the appearance of an anal fin occurred before the anaspids. Thus, an anal fin could be a plesiomorphic characteristic of vertebrates or even of craniates if the ventral fin of Myxinikela is homologous to an anal fin. An anal fin is absent in the oldest fossil lamprey, Priscomyzon, but phylogenetic analyses resolve Mayomyzon as the most basal petromyzontid, while Priscomyzon is more derived [171-173]. As for more crownward taxa, the presence of an anal fin is considered primitive for chondrichthyans, acanthodians, and osteichthyans; its absence in some Paleozoic sharks (e.g., Cladoselache, stethacanthids, and symmoriids) is considered as a derived condition [174].

As opposed to the median ventral fin, the long-based dorsal fins of myllokunmingiids are not so rapidly modified into shorter-based dorsal fins. Many agnathan taxa bear short-based and comparatively more posteriorly positioned dorsal fins (Petromyzontiformes, Loganelliiformes, Shieliiformes, Phlebolepidiformes, Furcacaudiformes, Osteostraci), whereas the Jamoytiiformes retain elongated dorsal fins. Long-based dorsal fins also occur in numerous chondrichthyan (e.g., Pleuracanthus gaudryi, Chondrenchelys problematica) and osteichthyan (e.g., Regalescus glesne, Acanthurus major) taxa. It is 
reasonable to assume that the dorsal fin is not constrained in its anterior extent and position, as opposed to the anal fin, which cannot extend anteriorly past the position of the anus. The Gymnotiformes provide a striking example: these fishes have elongated anal fins that extend along the majority of the ventral midline of the body, yet the anus is displaced anteriorly in these forms, positioned under the pectoral fins or even under the head, thus remaining in front of the anterior limit of the anal fin [175-177].

\section{Duplications of the dorsal fins}

Duplications of the dorsal fin seem to have occurred numerous times independently during the evolutionary history of fishes. Most extant lampreys have two dorsal fins. Among osteostracans, Ateleaspis, Aceraspis, and Hirella possess two dorsal fins and are resolved as basal members of this group [15, 178-181]. Among the most basal orders of placoderms, antiarchs and stensioellids generally possess a single dorsal fin, but the material for brindabellaspids and pseudopetalichthyids precludes interpretation of dorsal fin characters. In other groups of placoderms where dorsal fin characters are known, ptyctodontids have two dorsal fins, whereas rhenanids and arthrodires have a single dorsal fin. Among acanthodians, climatiiforms, diplacanthiforms, and ischnacanthiforms have two dorsal fins. Acanthodiforms possess a single dorsal fin, but this is considered as secondarily derived for this group.

Lund [174] expressed that the plesiomorphic condition for the number of dorsal fins in chondrichthyans could not be determined at the time and could just as well have been a single dorsal fin or two dorsal fins. The most basal articulated undisputed elasmobranchs known from the fossil record, Doliodus problematicus and Antarctilamna prisca, have anterior dorsal fins, but most of the postcranial region is unknown and thus insufficient to assess the presence of a posterior dorsal fin [182, 183]. Additionally, in the Antarctilamna material, a spine with a shallow insertion that had initially been interpreted as a displaced dorsal fin spine is now thought to be a pectoral fin spine, whereas a second type of spine with a deeper insertion is interpreted as a median fin [109, 183, 184]. Furthermore, phylogenies have not reached a stable consensus concerning the interrelationships of basal Euchondrocephali (see, e.g., [185-187]). Our supertree analysis places the iniopterygians as the most basal euchondrocephalan order, although they are resolved as the sister clade to all other chondrichthyans in Lund et al. [186]. Of course, in light of the growing support for the hypothesis that acanthodians are stem chondrichthyans, this would imply that the plesiomorphic condition for the total group chondrichthyans is in fact the presence of two dorsal fins.
Among osteichthyans, the presence of two dorsal fins has been considered as plesiomorphic [188]. Guiyu oneiros, resolved as a stem sarcopterygian [60], was originally reconstructed with a single dorsal fin [189], but has recently been reinterpreted as having two dorsal fins [190]. All other sarcopterygians have two dorsal fins, with the exception of a few dipnoans, elpistostegalians, and tetrapods. The Early Devonian Dialipina is resolved either as a basal osteichthyan $[54,55,58,59,61,191-$ $193]$ or as the most basal actinopterygian [57, 99, 102, 189, 194-197], and it possesses two dorsal fins [99]. Among other non-acanthomorph actinopterygians, a second dorsal fin is also found in a single fossil Ionoscopiformes species [100] and in a few extant Siluriformes belonging to the Plotosidae [1, 198-200]. This suggests that the presence of two dorsal fins would have been lost early during actinopterygian evolution [102], but that this character would have subsequently been reacquired more than once independently.

Acanthomorphs are characterized by the possession of an anterior spinous dorsal fin [201]. In some taxa the spinous and soft dorsal fins are continuous and connected by a fin web, whereas in others they are widely separated. In our scoring of characters, we considered that dorsal fins where the bases were not connected by a fin web constituted separate dorsal fins. The dorsal fin(s) of acanthomorphs can be interpreted in two different ways. One hypothesis is that the acanthopterygian anterior spinous dorsal fin results from a duplication of the posterior soft dorsal fin module [39]. Another hypothesis is that the second or third dorsal fin in acanthopterygians results from the subdivision of an originally more elongated fin [202]. As such, acanthomorphs retain a single dorsal fin which is regionalized, thus giving the impression that there are two (or three) dorsal fins [16]. Our supertree analysis places the Lampridiformes at the base of the acanthomorph radiation. The Aipichthyoidea, resolved as stem Lampridiformes [203, 204], possess a single dorsal fin, for which the anterior portion is generally supported by two to five fin spines [204-207], although there are 12 fin spines in Homalopagus multispinosus [207]. In crown Lampridiformes, dorsal fin spines are present in Veliferidae but are considered to have been secondarily lost in other forms [203]. Among other acanthomorph orders that were resolved as the most basal in our supertree analysis, Percopsiformes and Polymixiiformes also possess a single dorsal fin where the leading edge is generally supported by a few spines [1]. In light of this evidence, the hypothesis of a regionalized dorsal fin cannot be ignored.

Taken together, the phylogenetic distribution of dorsal fin conditions suggests that duplications of the dorsal fin occurred multiple times during the evolutionary history of fishes. It also suggests that two dorsal fins might have 
been the condition for the common ancestor to both osteostracans and gnathostomes. This character would have subsequently been lost and then occasionally reacquired in many fish lineages.

\section{Paired fins}

The first evidence of true paired fins in craniates is in the Anaspidiformes and Jamoytiiformes, generally in the form of long ribbon-like paired folds that are ventrolateral in position. A notable exception can be found in the Myxiniformes, where for a single genus, Neomyxine, we tentatively scored for the presence of ventrolateral paired fins. Neomyxine possesses paired folds of skin located immediately above the gill openings [208-210]. These skin folds are not used for swimming but rather as support when specimens settle on the substrate [209]. Furthermore, because these structures are located dorsally to the branchial apertures and because Neomyxine is not basal relative to other hagfishes, these paired skin folds are unlikely to be homologous to the ventrolateral paired fins found in other agnathans $[49,211]$, although some thelodonts also have paired fins that are inserted dorsally to the branchial apertures [63]. Thus, excluding Neomyxine, ventrolateral paired fins appear with the anaspids and can also be found in some thelodonts. The question regarding the homology of these paired fins has been debated for many years. Some authors consider that true paired fins must be constricted and supported by an endoskeletal girdle and fin radials [47, 48]. An alternative hypothesis is that paired fins evolved first as lateral extensions of the body, and that paired girdles only appeared later during the evolutionary history of basal vertebrates $[109,212]$. Shubin et al. [17] proposed an evolutionary scenario whereby (1) paired fins first appeared as elongated ventrolateral expansions along the body wall, (2) these expansions were then modified into shorter-based pectoral appendages only, (3) and later pelvic fins appeared among gnathostomes as serial homologues of the pectoral fins. We find the latter hypothesis reasonable: it would not be surprising that paired and unpaired fins share a similar evolutionary history (Fig. 4) considering the remarkable anatomical and developmental similarities between the paired and unpaired fins [41, 151, 213]. Furthermore, based on gene expression patterns during fin development in lampreys and sharks, it was suggested that the genetic programming associated with median fin development was subsequently redeployed to the lateral mesodermal plate, giving rise to the paired fins $[6,41]$. A previous study focusing on gene expression patterns in cephalochordates had similarly led Schubert et al. [214] to hypothesize that part of the developmental programs involved in tail outgrowth in basal chordates could have been co-opted towards paired appendage development in vertebrates.

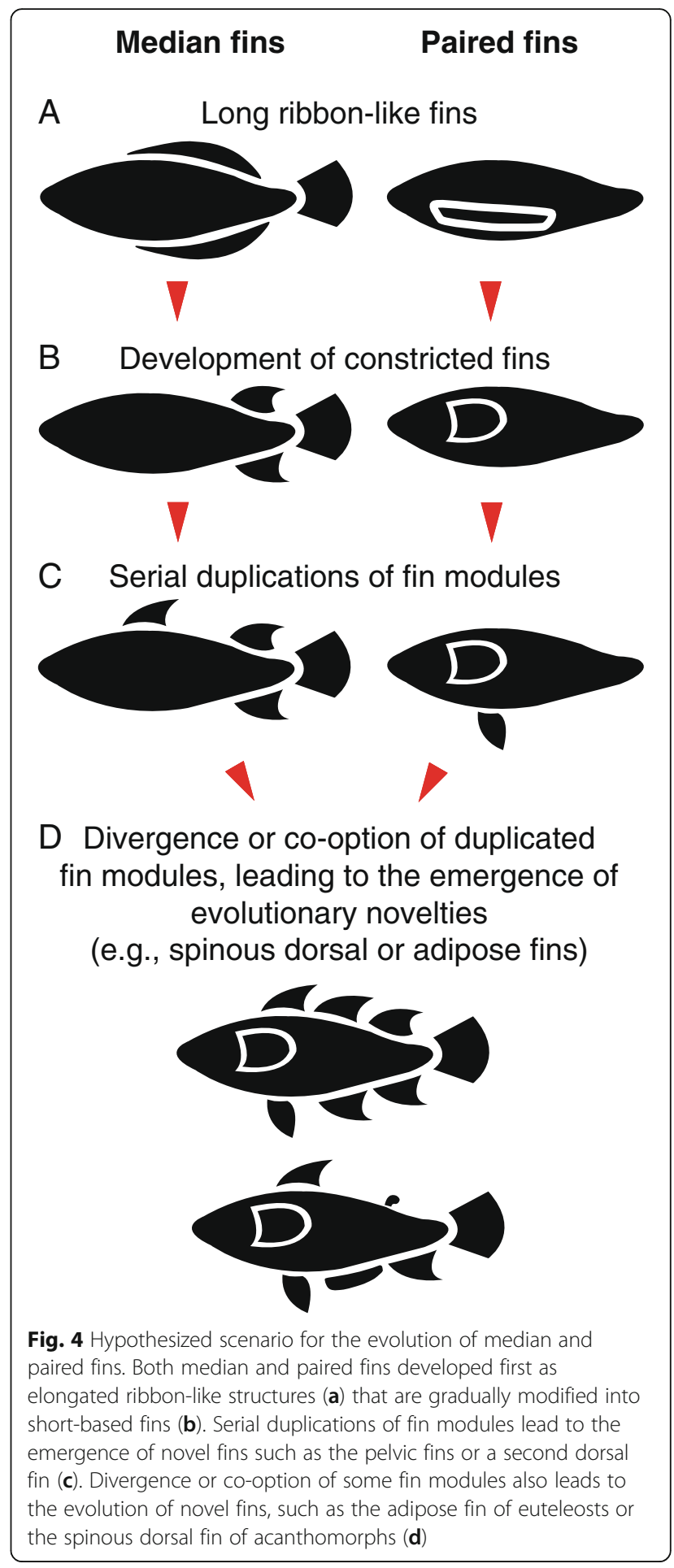

Alternatively, it could be argued that the pelvic fins, and not the pectoral fins appeared first [109], or that paired fins evolved multiple times independently during the evolutionary history of vertebrates [215].

As for short-based paired fins, true pectoral fins are considered to have appeared with the osteostracans, although pituriaspids also have pectoral fenestrae, 
suggesting that pectoral fins were present in these taxa as well [216]. The pectoral fins of osteostracans are supported by endoskeletal elements and are under muscular control: they can thus be considered as homologous to the pectoral fins of gnathostomes [11, 13, 15]. Additionally, some thelodonts possess muscularized and moveable paired fins that are in a pectoral position [11, 63, 217]. Girdle-supported pelvic fins are absent in agnathans [18, 47, 190, 211] and are first observed among placoderms $[16,18,19]$. Antiarch placoderms have been resolved at the base of the gnathostome diversification in most of the recent phylogenetic studies [54$57,59,61$ ] and were thought to be devoid of pelvic fins [65]. However, Zhu et al. [18] recently described a pelvic girdle in Parayunnanolepis. Additionally, our supertree analysis places the Pseudopetalichthyida stemward to the antiarch placoderms, making it the most basal gnathostome order. The most well-preserved pseudopetalichthyid articulated material belongs to Pseudopetalichthys problematica, which is known to possess both pectoral and pelvic fins [218]. This suggests that the presence of pelvic fins is likely to be plesiomorphic for gnathostomes.

\section{Evidence for fin evolutionary modules}

Based on the mapping of fin characters on the supertree, some pairs of fins are more frequently associated, either through coordinated duplication events or through coordinated losses, which is congruent with hypotheses that together they form evolutionary modules. This is the case for the dorsal and anal fins where the presence of a second anal fin is associated with the presence of a second or third dorsal fin. Mabee et al. [39] suggested that the dorsal and anal fins were linked through the presence of both positioning and patterning modules. Although patterning modules refer to the development of endo- and exoskeletal supports [39, 40, 219], the effect of the patterning module could extend to the resorption of the larval median finfold. More precisely, during fish larval development, there are generally dorsal and ventral median finfolds that are continuous with a caudal finfold [150, 151]. During development, these finfolds are resorbed except in places where dorsal, anal, and caudal fins will develop [151]. Here, we hypothesize that the mechanism underlying duplication of a nonresorption zone of the larval finfold could very well be reflected dorso-ventrally, leading to coordinated duplications of the dorsal and anal fins. This pattern also emerges in their coordinated loss patterns. For instance, in actinopterygians, results from the multiple correspondence analyses suggest that loss of the dorsal, anal, and caudal fins can be coordinated. Likewise, the results also show that loss of the pectoral and pelvic fins can be coordinated. Coordination of fin losses is not limited to actinopterygians: the results of the multiple correspondence analyses for chondrichthyans and sarcopterygians also show coordinated losses of the median fins. Evidence for a dorsal and anal fins evolutionary module has been proposed for lungfish, in light of the observations that, in earlier forms, the dorsal and anal fins present equivalent positions along the antero-posterior body axis, that they have similar morphologies, particularly with respect to fin supports, and that they were coordinately lost at the end of the Devonian [220]. It is unclear, however, if the dorsal and anal fins module suggested in Johanson et al. [220] involves the anterior dorsal fin, the posterior dorsal fin, or both dorsal fins. At a population scale, it was found that in the Arctic charr (Salvelinus alpinus), anatomical and developmental patterning of the dorsal and anal fins were highly similar, but differed largely from that of the caudal fin: this was interpreted as supporting the patterning modules proposed by Mabee et al. [39] for the dorsal and anal fins [219, 221]. A patterning module was also hypothesized for the caudal fin [219]. In contrast, in a recent study focusing on variational modularity in two cyprinid species, we showed good support for the hypothesis that the dorsal, anal, and caudal fins formed one variational module including the caudal peduncle, while the paired fins formed another variational module [222]. Because modularity is a hierarchical concept, a hypothesis of evolutionary modularity worth investigating is that the median fin system as a whole could constitute one module, the paired fin system could constitute a second independent module, and the dorsal and anal fins could constitute a third module nested within the median fins module (Fig. 5). Quasi-independent median and paired fin modules would help explain why there is so much disparity in median fin configurations in chondrichthyans, compared to the paired fins, which are largely unaffected.

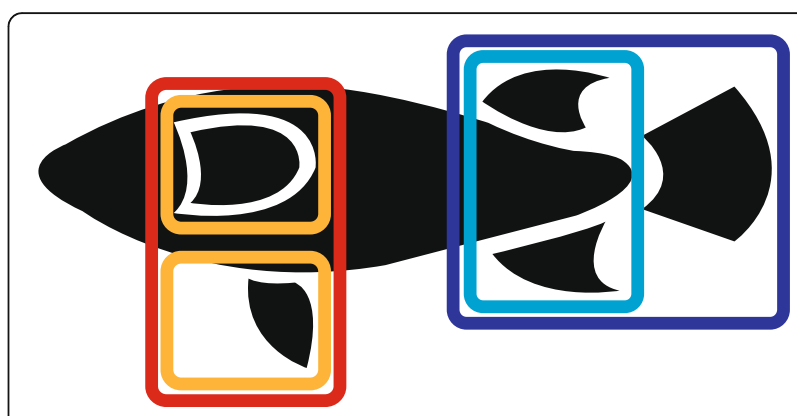

Fig. 5 Hypothesized fin modules. The pectoral and pelvic fins form a paired fins evolutionary module that can be dissociated, leading to individualized pectoral and pelvic fin modules. The dorsal and anal fins form a second evolutionary fin module nested within a larger median fins evolutionary module 
We have demonstrated that the co-occurrence of some sets of fins is non-random. Among these, the pectoral, pelvic, dorsal, anal, and caudal fins have all been found to be non-independent. This reflects the most common fin combinations found in the dataset where all of these fins cooccur, more specifically, the fin combinations that are characteristic of most actinopterygian orders (single dorsal and anal fins, a caudal fin, pectoral and pelvic fins) and of most chondrichthyan and sarcopterygian orders (two dorsal fins, a single anal fin, a caudal fin, pectoral and pelvic fins). When the analysis focuses on unique fin combinations, only the pectoral/pelvic fins show non-independence. The strong relationship between the pectoral and pelvic fins is concurrent with hypotheses that they form a paired fins evolutionary module.

A relationship was also found between the adipose fin and the median ventral fin. The adipose fin is considered as an evolutionary novelty among teleostean taxa and might also constitute a new fin module $[103,110]$. An adipose fin evolved at least twice independently, once within the Otophysi and a second time in the Euteleostei $[5,103]$. Development of the adipose fin is known to differ between otophysans and euteleosteans, supporting the hypothesis of multiple independent origins: in Characiformes, the adipose fin appears as an outgrowth following the complete resorption of the larval finfold, while in Salmoniformes, it develops as a remnant of the larval finfold [5]. As for the median ventral fin, the positive relationship with the adipose fin stems from a few euteleostean families that, in addition to the adipose fin, possess a rayless finfold in front of the anal fin that is often described as a ventral adipose fin (Retropinnidae, Stomiidae, Paralepididae). However, a similar ventral fin is also found in at least one family, the Sundasalangidae (Clupeiformes), prior to the appearance of the adipose fin, as well as in euteleostean families that do not have adipose fins (Phallostethidae, Hypoptychidae). As opposed to the adipose fin which has been the object of numerous recent investigations $[5,103$, $111,147,148]$, to our knowledge no work has focused on the origin or homology of the so-called ventral adipose fin. Developmental and histological work would be necessary to establish if this median ventral fin is homologous among these taxa.

A dorsal-anal fin module is well supported by developmental data $[40-42,219,221,223]$. It has also been inferred based on the similarities in the relative positioning of these two fins across species [39]. Because the positioning module inferred by Mabee et al. [39] has been identified at a macroevolutionary scale, it qualifies as an evolutionary module. Herein, we provide further evidence for a dorsal-anal fin evolutionary module, with indications that its effect also extends to the coordinated losses and duplications of these fins in different species.
Co-occurrence of the pectoral and pelvic fins is extremely well supported in our analyses. Both paleontological and embryological studies support the idea that the pelvic fins could have originated by a duplication of the pectoral fins module [20, 21, 224, 225]. Based on this hypothesis, it follows that the co-occurrence of these two fins would be expected. An alternative possibility is that the pectoral and pelvic fin modules have dissociated and become independent modules during the evolutionary history of fishes [10, 20, 45, 46, 226]. As evidence for this latter hypothesis, Coates and Cohn [10] mentioned that there is no example in which the pelvic appendages are a direct copy or identical serial homologues of the pectoral fins. Additionally, some primitive gnathostomes (e.g., Parayunnanolepis, Kathemacanthus, Lupopsyrus, Brochoadmones, Cheirolepis) have pectoral and pelvic fins that are both anatomically different and positionally decoupled [109]. One could argue, however, that the paired fins present extremely similar morphologies in chimaerids (C. Riley and E. Grogan, personal communication; R. Cloutier, personal observation) and in many sarcopterygians [188, 190]. Furthermore, biserial fin designs evolved convergently in pectoral and pelvic fins in some chondrichthyan and sarcopterygian taxa, as did uniserial fin designs in osteolepiforms [105]. Considering that independent loss of the pectoral or pelvic fins occurs almost only in actinopterygians, perhaps the dissociation of the paired fins module is a generalized characteristic for this group, which was independently acquired in eugeneodontiform sharks.

\section{Conclusions}

Although the sequential emergence of fins among fishes has been discussed on empirical grounds, the results from this analysis support a longstanding idea that both the median and paired fins would have appeared first as long-based or ribbon-like structures, before being modified into more spatially constricted appendages. Additionally, for the first time, we have a quantified picture of the covariation in fin presence at a large phylogenetic scale. Our results highlight that even with a dataset comprising semi-quantitative characters, there is compelling evidence that the pectoral and pelvic fins, and the dorsal and anal fins form two distinct evolutionary modules. The results also suggest an interesting hypothesis whereby the dorsal/anal fins module could be nested within a larger median fins module. Combined with the results from our previous analysis on variational modularity in cyprinids [222], this suggests that patterns of morphological integration and modularity that are identified within populations can translate into integration at a macroevolutionary scale. An important next step will be to validate this hypothesis using fully quantitative methods, as well as to investigate the consequences of these putative evolutionary modules on patterns of 
morphological disparity. Because the hypotheses of modularity that we are testing are largely based on evidence from developmental data, this would provide a striking example linking developmental to variational and evolutionary modules.

\section{Additional files}

Additional file 1: Source trees and additional results of the supertree analyses. A: List of source trees that were incorporated into the MRP supertree analysis. B: 50\% majority rule consensus of the supertrees obtained using Nixon's Parsimony Ratchet. C: Strict consensus of the supertrees obtained using Nixon's Parsimony Ratchet. D: Supertree obtained using optimum parsimony. E: Insights of the supertree into basal vertebrate interrelationships. (PDF $510 \mathrm{~kb}$ )

Additional file 2: A CSV file containing fin characters that were mapped on the supertree and analyzed. (CSV $28 \mathrm{~kb}$ )

Additional file 3: Additional results of the multiple correspondence analyses focusing on gnathostomes and osteichthyans. A: Biplot of the first two dimensions of the MCA focusing on gnathostomes. B: Biplot of the first two dimensions of the MCA focusing on osteichthyans. C: Description of additional multiple correspondence analyses results. (PDF $217 \mathrm{~kb}$ )

\section{Acknowledgements}

The authors are grateful to M. Chevrinais, L. Fischer-Rousseau, T. Grande, T. Grünbaum, C. Riley, M.V.H. Wilson and one anonymous reviewer for enlightening conversations and/or insightful comments, to A. Caron for statistical advice and to V.E. Roy for his suggestions in graphical design

\section{Funding}

This research was partly funded by the Natural Sciences and Engineering Research Council of Canada (BESC-M and PGS-D to OL; NSERC Discovery Grant 238612 to RC) and the Fonds de Recherche Nature et Technologies Québec (B1 to OL).

\section{Availability of data and materials}

All data generated or analyzed during this study are included in this published article (and its Additional files).

\section{Authors' contributions}

$\mathrm{OL}$ and RC designed the study. OL collected and analyzed the data. All authors participated in drafting the manuscript. All authors read and approved the final manuscript.

\section{Competing interests}

The authors declare that they have no competing interests.

\section{Consent for publication}

Not applicable.

\section{Ethics approval and consent to participate}

Not applicable.

\section{Publisher's Note}

Springer Nature remains neutral with regard to jurisdictional claims in published maps and institutional affiliations.

\section{Author details}

${ }^{1}$ Laboratoire de Paléontologie et de Biologie évolutive, Université du Québec à Rimouski, Rimouski, Québec G5L 3A1, Canada. ${ }^{2}$ Museum of Paleontology, University of Michigan, Ann Arbor, MI 48109, USA.
Received: 24 November 2016 Accepted: 26 March 2017

Published online: 27 April 2017

\section{References}

1. Nelson JS, Grande TC, Wilson MVH. Fishes of the world. 5th ed. Hoboken: Wiley; 2016

2. Aristotle CR, Schneider JG. Aristotle's history of animals in ten books. London: George Bell \& Sons; 1878.

3. Cuvier G, Valenciennes M. Histoire naturelle des poissons, Tome premier. Paris: F.G. Levrault; 1828

4. Lacépède BGE. Histoire naturelle des poissons, Tome premier. Paris: Plassan; 1798

5. Stewart TA, Smith WL, Coates MI. The origins of adipose fins: an analysis of homoplasy and the serial homology of vertebrate appendages. Proc R Soc B-Biol Sci. 2014;281:20133120.

6. Freitas R, Gómez-Skarmeta JL, Rodrigues PN. New frontiers in the evolution of fin development. J Exp Zool Part B. 2014;322B:540-52.

7. Shu DG, Luo HL, Morris SC, Zhang XL, Hu SX, Chen L, Han J, Zhu M, Li Y, Chen LZ. Lower Cambrian vertebrates from South China. Nature. 1999:402:42-6.

8. Shu DG, Morris SC, Han J, Zhang ZF, Yasui K, Janvier P, Chen L, Zhang XL, Liu JN, Li Y, et al. Head and backbone of the Early Cambrian vertebrate Haikouichthys. Nature. 2003;421:526-9.

9. Zhang XG, Hou XG. Evidence for a single median fin-fold and tail in the Lowe Cambrian vertebrate, Haikouichthys ercaicunensis. J Evol Biol. 2004;17:1162-6.

10. Coates MI, Cohn MJ. Fins, limbs, and tails: outgrowths and axial patterning in vertebrate evolution. Bioessays. 1998;20:371-81.

11. Coates Ml. The evolution of paired fins. Theory Biosci. 2003;122:266-87.

12. Forey PL. Agnathans recent and fossil, and the origin of jawed vertebrates. Rev Fish Biol Fish. 1995:5:267-303.

13. Forey $P$, Janvier $P$. Agnathans and the origin of jawed vertebrates. Nature. 1993;361:129-34.

14. Forey P, Janvier P. Evolution of the early vertebrates. Am Scientist. 1994;82: 554-65.

15. Sansom RS. Phylogeny, classification and character polarity of the Osteostraci (Vertebrata). J Syst Palaeontol. 2009;7:95-115.

16. Janvier P. Early vertebrates. Oxford: Oxford University Press; 1996.

17. Shubin N, Tabin C, Carroll S. Fossils, genes and the evolution of animal limbs. Nature. 1997;388:639-48.

18. Zhu M, Yu XB, Choo B, Wang JQ, Jia LT. An antiarch placoderm shows that pelvic girdles arose at the root of jawed vertebrates. Biol Lett. 2012:8:453-6.

19. Sansom RS, Gabbott SE, Purnell MA. Unusual anal fin in a Devonian jawless vertebrate reveals complex origins of paired appendages. Biol Lett. 2013:9:5.

20. Coates MI. The origin of vertebrate limbs. Development. 1994;1994(Suppl):169-80

21. Coates Ml. Hox genes, fin folds and symmetry. Nature. 1993:364:195-6.

22. Wagner GP. Homologues, natural kinds and the evolution of modularity. Am Zool. 1996:36:36-43.

23. Winther RG. Varieties of modules: kinds, levels, origins, and behaviors. J Exp Zool. 2001;291:116-29.

24. Klingenberg CP. Morphological integration and developmental modularity. Annu Rev Ecol Evol Syst. 2008;39:115-32.

25. Magwene PM. New tools for studying integration and modularity. Evolution. 2001;55:1734-45.

26. Müller GB. Evo-devo: extending the evolutionary synthesis. Nat Rev Genet. 2007:8:943-9.

27. Simon HA. The architecture of complexity. Proc Amer Phil Soc. 1962:106:467-82.

28. Raff RA. The shape of life: genes, development, and the evolution of animal form. Chicago: The University of Chicago Press; 1996.

29. Wagner GP, Mezey JG. The role of genetic architecture constraints in the origin of variational modularity. In: Schlosser G, Wagner GP, editors. Modularity in development and evolution. Chicago: The University of Chicago Press; 2004. p. 338-58.

30. Wagner GP, Pavlicev M, Cheverud JM. The road to modularity. Nat Rev Genet. 2007:8:921-31.

31. Cheverud JM. Developmental integration and the evolution of pleiotropy. Am Zool. 1996;36:44-50

32. Wagner GP, Altenberg L. Perspective: complex adaptations and the evolution of evolvability. Evolution. 1996;50:967-76.

33. Cheverud JM. Phenotypic, genetic, and environmental morphological integration in the cranium. Evolution. 1982;36:499-516.

34. Brandon RN. The units of selection revisited: the modules of selection. Biol Philos. 1999;14:167-80. 
35. Monteiro A. Alternative models for the evolution of eyespots and of serial homology on lepidopteran wings. Bioessays. 2008;30:358-66.

36. Riedl R. Order in living organisms: a systems analysis of evolution. Chichester: Wiley; 1978.

37. Weiss KM. Duplication with variation: metameric logic in evolution from genes to morphology. Yearb Phys Anthropol. 1990;33:1-23.

38. Savriama Y, Vitulo M, Gerber S, Debat V, Fusco G. Modularity and developmental stability in segmented animals: variation in translational asymmetry in geophilomorph centipedes. Dev Genes Evol. 2016;226: 187-96.

39. Mabee $P M$, Crotwell PL, Bird NC, Burke AC. Evolution of median fin modules in the axial skeleton of fishes. J Exp Zool B Mol Dev Evol. 2002;294:77-90

40. Cloutier R. The fossil record of fish ontogenies: insights into developmental patterns and processes. Semin Cell Dev Biol. 2010;21:400-13.

41. Freitas R, Zhang GJ, Cohn MJ. Evidence that mechanisms of fin development evolved in the midline of early vertebrates. Nature. 2006:442:1033-7.

42. Crotwell PL, Clark TG, Mabee PM. Gdf5 is expressed in the developing skeleton of median fins of late-stage zebrafish, Danio rerio. Dev Genes Evol. 2001;211:555-8.

43. Crotwell PL, Mabee PM. Gene expression patterns underlying proximal-distal skeletal segmentation in late-stage zebrafish, Danio rerio. Dev Dyn. 2007;236: 3111-28.

44. Hadzhiev Y, Lele Z, Schindler S, Wilson SW, Ahlberg P, Strahle U, Muller F. Hedgehog signaling patterns the outgrowth of unpaired skeletal appendages in zebrafish. BMC Dev Biol. 2007;7:12.

45. Coates MI, Jeffery JE, Ruta M. Fins to limbs: what the fossils say. Evol Dev. 2002:4:390-401.

46. Hall BK. Charles Darwin, embryology, evolution and skeletal plasticity. J Appl Ichthyol. 2010;26:148-51.

47. Johanson Z. Evolution of paired fins and the lateral somitic frontier. J Exp Zool B Mol Dev Evol. 2010;314B:347-52.

48. Janvier $P$. The dawn of the vertebrates: characters versus common ascent in the rise of current vertebrate phylogenies. Paleontology. 1996;39:259-87.

49. Donoghue PCJ, Forey PL, Aldridge RJ. Conodont affinity and chordate phylogeny. Biol Rev. 2000;75:191-251.

50. Donoghue PCI, Smith MP. The anatomy of Turinia pagei (Powrie), and the phylogenetic status of the Thelodonti. Trans R Soc Edinb-Earth Sci. 2001;92:15-37.

51. Sansom RS, Freedman K, Gabbott SE, Aldridge RJ, Purnell MA. Taphonomy and affinity of an enigmatic Silurian vertebrate, Jamoytius kerwoodi White. Paleontology. 2010;53:1393-409.

52. Turner S, Burrow CJ, Schultze HP, Blieck A, Reif WE, Rexroad CB, Bultynck $P$, Nowlan GS. False teeth: conodont-vertebrate phylogenetic relationships revisited. Geodiversitas. 2010;32:545-94.

53. Keating JN, Donoghue PCJ. Histology and affinity of anaspids, and the early evolution of the vertebrate dermal skeleton. Proc R Soc B-Biol Sci. 2016;283: 20152917

54. Brazeau MD. The braincase and jaws of a Devonian 'acanthodian' and modern gnathostome origins. Nature. 2009;457:305-8.

55. Davis PD, Finarelli JA, Coates MI. Acanthodes and shark-like conditions in the last common ancestor of modern gnathostomes. Nature. 2012:486:247-51.

56. Zhu M, Yu XB, Ahlberg PE, Choo B, Lu J, Qiao T, Qu QM, Zhao WJ, Jia LT, Blom $\mathrm{H}$, et al. A Silurian placoderm with osteichthyan-like marginal jaw bones. Nature. 2013;502:188-93.

57. Long JA, Mark-Kurik E, Johanson Z, Lee MSY, Young GC, Min Z, Ahlberg PE, Newman M, Jones R, den Blaauwen J, et al. Copulation in antiarch placoderms and the origin of gnathostome internal fertilization. Nature. 2015;517:196-9.

58. Giles S, Friedman M, Brazeau MD. Osteichthyan-like cranial conditions in an Early Devonian stem gnathostome. Nature. 2015;520:82-5.

59. Burrow C, den Blaauwen J, Newman M, Davidson R. The diplacanthid fishes (Acanthodii, Diplacanthiformes, Diplacanthidae) from the Middle Devonian of Scotland. Palaeontol Electron. 2016;19.1.10A:1-83.

60. Qiao T, King B, Long JA, Ahlberg P, Zhu M. Early gnathostome phylogeny revisited: multiple method consensus. PLoS ONE. 2016;11:e0163157.

61. Dupret V, Sanchez S, Goujet D, Tafforeau P, Ahlberg PE. A primitive placoderm sheds light on the origin of the jawed vertebrate face. Nature. 2014:507:500-3.

62. Froese R, Pauly D. Fishbase. 2016. www.fishbase.org. Accessed 16 Nov 2016.

63. Märss T, Turner S, Karatajūtē-Talimaa V. Handbook of paleoichthyology, Volume 1B,"Agnatha" II:- Thelodonti. Munich: Verlag Dr. Friedrich Pfeil; 2007.
64. Denison RH. Handbook of paleoichthyology, Volume 2, Placodermi. Stuttgart: Gustav Fischer Verlag; 1978.

65. Young GC. Placoderms (armored fish): dominant vertebrates of the Devonian period. Annu Rev Earth Planet Sci. 2010;38:523-50.

66. Ginter M, Hampe O, Duffin C. Handbook of paleoichthyology, Volume 3D, Chondrichthyes: Paleozoic Elasmobranchii: teeth. Munich: Verlag Dr. Friedrich Pfeil; 2010

67. Stahl BJ. Handbook of paleoichthyology, Volume 4, Chondrichthyes III: Holocephali. Munich: Verlag Dr. Friedrich Pfeil; 1999.

68. Cloutier R, Ahlberg PE. Morphology, characters, and the interrelationships of basal sarcopterygians. In: Stiassny MLJ, Parenti LR, Johnson GD, editors. Interrelationships of fishes. San Diego: Academic Press; 1996. p. 445-79.

69. Patterson C. Morphological characters and homology. In: Joysey KA, Friday $A E$, editors. Problems of phylogenetic reconstruction. London: Academic Press; 1982. p. 21-74.

70. Baum BR. Combining trees as a way of combining data sets for phylogenetic inference, and the desirability of combining gene trees. Taxon. 1992;41:3-10.

71. Baum BR, Ragan MA. The MRP method. In: Bininda-Emonds ORP, editor. Phylogenetic supertrees - combining information to reveal the tree of life. Dordrecht: Kluwer Academic Publishers; 2004. p. 17-34.

72. Ragan MA. Phylogenetic inference based on matrix representation of trees. Mol Phylogenet Evol. 1992;1:53-8.

73. Bininda-Emonds ORP, Sanderson MJ. Assessment of the accuracy of matrix representation with parsimony analysis supertree construction. Syst Biol. 2001;50:565-79.

74. Bininda-Emonds ORP, Gittleman JL, Steel MA. The (super)tree of life: procedures, problems, and prospects. Annu Rev Ecol Syst. 2002;33:265-89.

75. Bininda-Emonds ORP. New uses for old phylogenies - an introduction to the volume. In: Bininda-Emonds ORP, editor. Phylogenetic supertrees combining information to reveal the tree of life. Dordrecht: Kluwer Academic Publishers; 2004. p. 1-14.

76. Gatesy J, Springer MS. A critique of matrix representation with parsimony supertrees. In: Bininda-Emonds ORP, editor. Phylogenetic supertrees combining information to reveal the tree of life. Dordrecht: Kluwer Academic Publishers; 2004. p. 369-88.

77. Purvis A. A modification to Baum and Ragan's method for combining phylogenetic trees. Syst Biol. 1995:44:251-5.

78. Bininda-Emonds ORP, Bryant HN. Properties of matrix representation with parsimony analyses. Syst Biol. 1998;47:497-508.

79. Klug S, Kriwet J. Timing of deep-sea adaptation in dogfish sharks: insights from a supertree of extinct and extant taxa. Zool Scr. 2010;39:331-42.

80. Schliep KP. phangorn: phylogenetic analysis in R. Bioinformatics. 2011;27: 592-3.

81. R Core Team. R: a language and environment for statistical computing. Vienna: R Foundation for Statistical Computing; 2016. https://www.R-project.org/.

82. Nixon KC. The Parsimony Ratchet, a new method for rapid parsimony analysis. Cladistics. 1999;15:407-14.

83. Bininda-Emonds ORP, Jones KE, Price SA, Cardillo M, Grenyer R, Purvis A Garbage in, garbage out: data issues in supertree construction. In: Bininda-Emonds ORP, editor. Phylogenetic supertrees - combining information to reveal the tree of life. Dordrecht: Kluwer Academic Publishers; 2004. p. 267-80.

84. Bryant HN. The cladistics of matrix representation with parsimony. In: Bininda-Emonds ORP, editor. Phylogenetic supertrees — combining information to reveal the tree of life. Dordrecht: Kluwer Academic Publishers; 2004. p. 353-68.

85. Gatesy J, Matthee C, DeSalle R, Hayashi C. Resolution of a supertree/ supermatrix paradox. Syst Biol. 2002;51:652-64.

86. Purvis A. A composite estimate of primate phylogeny. Philos Trans R Soc Lond B-Biol Sci. 1995;348:405-21.

87. Bininda-Emonds ORP, Gittleman JL, Purvis A. Building large trees by combining phylogenetic information: a complete phylogeny of the extant Carnivora (Mammalia). Biol Rev. 1999;74:143-75.

88. Springer MS, de Jong WW. Phylogenetics — which mammalian supertree to bark up? Science. 2001;291:1709-11.

89. Rodrigo AG. On combining cladograms. Taxon. 1996;45:267-74.

90. Rodrigo AG. A comment on Baum's method for combining phylogenetic trees. Taxon. 1993;42:631-6.

91. Novacek MJ. Mammalian phylogeny: genes and supertrees. Curr Biol. 2001; 11:R573-5. 
92. Nenadic O, Greenacre M. Correspondence analysis in R, with two- and three-dimensional graphics: the ca package. J Stat Softw. 2007;20:1-13.

93. Harrell FE. Hmisc: Harrell Miscellaneous. 2016. https://cran.r-project.org/web/ packages/Hmisc/index.html.

94. Lemaire P. Evolutionary crossroads in developmental biology: the tunicates. Development. 2011:138:2143-52.

95. Stensiö EA. Les cyclostomes fossiles ou ostracodermes. In: Piveteau J, editor. Traité de paléontologie Tome IV — L'origine des vertébrés, leur expansion dans les eaux douces et le milieu marin, Premier Volume: vertébrés (généralités), agnathes. Paris: Masson et Cie; 1964. p. 96-382.

96. Ritchie A. Phlebolepis elegans Pander, an Upper Silurian thelodont from Oesel, with remarks on the morphology of thelodonts. In: Ørvig T, editor. Current problems of lower vertebrate phylogeny: proceedings of the Fourth Nobel Symposium, vol. 4. Stockholm: Almqvist \& Wiskell; 1968. p. 81-8.

97. Turner S. A new articulated thelodont (Agnatha) from the Early Devonian of Britain. Paleontology. 1982;25:879-89.

98. Dineley DL, Loeffler EJ. Ostracoderm faunas from the Delorme and associated Siluro-Devonian formations, North West Territories, Canada. Spec Pap Palaeontol. 1976;18:1-214.

99. Schultze HP, Cumbaa SL. Dialipina and the characters of basal actinopterygians. In: Ahlberg PE, editor. Major events in early vertebrate evolution: palaeontology, phylogeny, genetics and development. London: Taylor \& Francis; 2001. p. 315-32.

100. Brito PM. A new halecomorph with two dorsal fins, Placidichthys bidorsalis $n$. g., n. sp. (Actinopterygii: Halecomorphi) from the Lower Cretaceous of the Araripe Basin, northeast Brazil. Comptes Rendus Acad Sci Ser II-A. 2000;331: 749-54.

101. Hanke GF. Paucicanthus vanelsti gen. et sp. nov., an Early Devonian (Lochkovian) acanthodian that lacks paired fin-spines. Can J Earth Sci. 2002;39:1071-83.

102. Cloutier R, Arratia G. Early diversification of actinopterygians. In: Arratia G, Wilson MVH, Cloutier R, editors. Recent advances in the origin and early radiation of vertebrates. Munich: Verlag Dr. Friedrich Pfeil; 2004. p. 217-70,

103. Stewart TA, Hale ME. First description of a musculoskeletal linkage in an adipose fin: innovations for active control in a primitively passive appendage. Proc R Soc B-Biol Sci. 2013;280:20122159.

104. Ahlberg PE. Paired fin skeletons and relationships of the fossil group Porolepiformes (Osteichthyes: Sarcopterygii). Zool J Linn Soc. 1989;96:119-66.

105. Shubin NH. Origin of evolutionary novelty: examples from limbs. J Morphol. 2002;252:15-28.

106. Shubin N, Tabin C, Carroll S. Deep homology and the origins of evolutionary novelty. Nature. 2009;457:818-23.

107. Shubin NH, Daeschler EB, Jenkins FA. The pectoral fin of Tiktaalik roseae and the origin of the tetrapod limb. Nature. 2006;440:764-71.

108. Daeschler EB, Shubin NH, Jenkins FA. A Devonian tetrapod-like fish and the evolution of the tetrapod body plan. Nature. 2006;440:757-63.

109. Wilson MVH, Hanke GF, Märss T. Paired fins of jawless vertebrates and their homologies across the "agnathan"-gnathostome transition. In: Anderson JS, Sues HD, editors. Major transitions in vertebrate evolution. Bloomington: Indiana University Press; 2007. p. 122-49.

110. Maisey JG. The spine-brush complex in symmoriiform sharks (Chondrichthyes; Symmoriiformes), with comments on dorsal fin modularity. J Vertebr Paleontol. 2009;29:14-24.

111. Stewart TA. The origin of a new fin skeleton through tinkering. Biol Lett 2015;11:5.

112. Hansen TF. Is modularity necessary for evolvability? Remarks on the relationship between pleiotropy and evolvability. Biosystems. 2003;69:83-94.

113. Hansen TF, Armbruster WS, Carlson ML, Pelabon C. Evolvability and genetic constraint in Dalechampia blossoms: genetic correlations and conditional evolvability. J Exp Zool B Mol Dev Evol. 2003;296B:23-39.

114. Bardack D. Relationships of living and fossil hagfishes. In: Jørgensen JM, Lomholt JP, Weber RE, Malte H, editors. The biology of hagfishes. London: Chapman \& Hall; 1998. p. 3-14.

115. Bardack D, Richardson ES. New agnathous fishes from the Pennsylvanian of Illinois. Fieldiana Geol. 1977:33:489-512.

116. Mok HK, Kuo CH. Myxine formosana, a new species of hagfish (Myxiniformes: Myxinidae) from the southwestern waters of Taiwan. Ichthyol Res. 2001;48:295-7.

117. McMillan CB, Wisner RL. Review of the hagfishes (Myxinidae, Myxiniformes) of the northwestern Pacific Ocean, with descriptions of three new species, Eptatretus fernholmi, Paramyxine moki, and P. walkeri. Zool Stud. 2004;43:51-73.

118. Zangerl R. Handbook of paleoichthyology, Volume 3A, Chondrichthyes I: Paleozoic Elasmobranchii. Stuttgart: Gustav Fischer Verlag; 1981.
119. Maisey JG. Heads and tails: a chordate phylogeny. Cladistics. 1986;2:201-56.

120. Grogan ED, Lund R, Greenfest-Allen E. The origin and relationships of early chondrichthyans. In: Carrier JC, Musick JA, Heithaus MR, editors. Biology of sharks and their relatives. 2nd ed. Boca Raton: CRC Press; 2012. p. 3-29.

121. Gess RW, Coates MI. High-latitude chondrichthyans from the Late Devonian (Famennian) Witpoort Formation of South Africa. Paläontol Z. 2015;89:147-69.

122. Rosenberger $L$. Pectoral fin locomotion in batoid fishes: undulation versus oscillation. J Exp Biol. 2001;204:379-94.

123. Schaefer JT, Summers AP. Batoid wing skeletal structure: novel morphologies, mechanical implications, and phylogenetic patterns. J Morphol. 2005;264:298-313.

124. Franklin O, Palmer C, Dyke G. Pectoral fin morphology of batoid fishes (Chondrichthyes: Batoidea): explaining phylogenetic variation with geometric morphometrics. J Morphol. 2014;275:1173-86.

125. Yamanoue Y, Setiamarga DHE, Matsuura K. Pelvic fins in teleosts: structure, function and evolution. J Fish Biol. 2010;77:1173-208.

126. Harris JE. The role of the fins in the equilibrium of the swimming fish. II. The role of the pelvic fins. J Exp Biol. 1938;15:32-47.

127. Harris JE. The role of the fins in the equilibrium of the swimming fish. I. Windtunnel tests on a model of Mustelus canis (Mitchill). J Exp Biol. 1936;13:476-93.

128. Lindsey CC. Form, function, and locomotory habits in fish. In: Hoar WS, Randall DJ, editors. Fish physiology, Volume VII, Locomotion. New York: Academic Press; 1978. p. 1-100.

129. Standen EM. Pelvic fin locomotor function in fishes: three-dimensional kinematics in rainbow trout (Oncorhynchus mykiss). J Exp Biol. 2008;211:2931-42.

130. Rade CM, Ward AB. Evolution of fin size and morphology in otophysan fishes. Integr Comp Biol. 2010;50:E285.

131. Ward AB, Mehta RS. Axial elongation in fishes: using morphological approaches to elucidate developmental mechanisms in studying body shape. Integr Comp Biol. 2010;50:1106-19.

132. Gans C. Tetrapod limblessness: evolution and functional corollaries. Am Zool. 1975;15:455-67.

133. Withers PC. Physiological correlates of limblessness and fossoriality in scincid lizards. Copeia. 1981;1981:197-204.

134. Adriaens D, Devaere S, Teugels GG, Dekegel B, Verraes W. Intraspecific variation in limblessness in vertebrates: a unique example of microevolution. Biol J Linnean Soc. 2002;75:367-77.

135. Hollò G, Novàk M. The manoeuvrability hypothesis to explain the maintenance of bilateral symmetry in animal evolution. Biol Direct. 2012;7. doi: 10.1186/1745-6150-7-22.

136. Webb PW. Hydrodynamics and energetics of fish propulsion. B Fish Res Board Can. 1975;190:1-158.

137. Joss J, Longhurst T. Lungfish paired fins. In: Ahlberg PE, editor. Major events in early vertebrate evolution: palaeontology, phylogeny, genetics and development. London: Taylor \& Francis; 2001. p. 370-6.

138. Faustino M, Power DM. Development of the pectoral, pelvic, dorsal and anal fins in cultured sea bream. J Fish Biol. 1999:54:1094-110.

139. Britz R, Conway KW. Osteology of Paedocypris, a miniature and highly developmentally truncated fish (Teleostei: Ostariophysi: Cyprinidae). J Morphol. 2009;270:389-412.

140. Bolin RL. A new stomiatoid fish from California. Copeia. 1939;1939:39-41.

141. Fink WL. Phylogenetic interrelationships of the stomiid fishes (Teleostei: Stomiiformes). Misc Pub Mus Zool Univ Mich. 1985;171:1-127.

142. Kawaguchi K, Moser HG. Stomiatoidea: development. In: Moser HG, Richards WJ, Cohen DM, Fahay MP, Kendall AW, Richardson SL, editors. Ontogeny and systematics of fishes based on an international symposium dedicated to the memory of Elbert Halvor Ahlstrom. Lawrence: The American Society of Ichthyologists and Herpetologists; 1984. p. 169-81.

143. Goodyear RH, Gibbs RH. Family No. 71: Malacosteidae. In: Smith MM, Heemstra PC, editors. Smith's sea fishes. Berlin: Springer-Verlag; 1986. p. 235-6.

144. Hulley PA. Family No. 70: Idiacanthidae. In: Smith MM, Heemstra PC, editors. Smith's sea fishes. Berlin: Springer-Verlag; 1986. p. 234-5.

145. Kenaley CP, Hartel KE. A revision of Atlantic species of Photostomias (Teleostei: Stomiidae: Malacosteinae), with a description of a new species. Ichthyol Res. 2005;52:251-63.

146. Ahlstrom EH, Amaoka K, Hensley DA, Moser HG, Sumida BY. Pleuronectiformes: development. In: Moser HG, Richards WJ, Cohen DM, Fahay MP, Kendall AW, Richardson SL, editors. Ontogeny and systematics of fishes based on an international symposium dedicated to the memory of Elbert Halvor Ahlstrom. Lawrence: The American Society of Ichthyologists and Herpetologists; 1984. p. 640-70. 
147. Reimchen TE, Temple NF. Hydrodynamic and phylogenetic aspects of the adipose fin in fishes. Can J Zool. 2004;82:910-6.

148. Temple NF, Reimchen TE. Adipose fin condition and flow regime in catfish. Can J Zool. 2008:86:1079-82

149. Hou XG, Aldridge RJ, Siveter DJ, Feng XH. New evidence on the anatomy and phylogeny of the earliest vertebrates. Proc R Soc Lond B-Biol Sci. 2002; 269:1865-9.

150. van den Boogaart JGM, Muller M, Osse JWM. Structure and function of the median finfold in larval teleosts. J Exp Biol. 2012;215:2359-68.

151. Bemis WE, Grande L. Development of the median fins of the North American paddlefish (Polyodon spathula), and a reevaluation of the lateral fin-fold hypothesis. In: Arratia G, Schultze H-P, editors. Mesozoic fishes 2 - systematics and fossil record. Munich: Verlag Dr. Friedrich Pfeil; 1999. p. 41-68.

152. Andrews EA. An undescribed acraniate: Asymmetron lucayanum. Stud Biol Lab Johns Hopkins Univ. 1893;5:213-47.

153. Kirkaldy JW. A revision of the genera and species of the Branchiostomidae. Q J Microsc Sci. 1895;37:303-23.

154. Bigelow HB, Farfante IP. Lancelets. In: Tee-Van J, Breder CM, Hildebrand SF, Parr AE, Schroeder WC, editors. Fishes of the western North Atlantic part 1 lancelets, cyclostomes, sharks. New Haven: Sears Foundation for Marine Research, Yale University; 1948. p. 1-28.

155. Rice HJ. Observations upon the habits, structure and development of Amphioxus lanceolatus. Am Nat. 1880;14:1-19.

156. Lankester ER. Contributions to the knowledge of Amphioxus lanceolatus, Yarrell. Q J Microsc Sci. 1889;29:365-408.

157. Sansom RS, Gabbott SE, Purnell MA. Decay of vertebrate characters in hagfish and lamprey (Cyclostomata) and the implications for the vertebrate fossil record. Proc R Soc B-Biol Sci. 2011:278:1150-7.

158. Sansom RS, Gabbott SE, Purnell MA. Non-random decay of chordate characters causes bias in fossil interpretation. Nature. 2010;463:797-800.

159. Kiaer J. The Downtonian fauna of Norway. I. Anaspida, with a geological introduction. Vidensk Selsk Skrift I Math-Naturv Klasse. 1924;6:1-139.

160. Stetson HC. A restoration of the anaspid Birkenia elegans Traquair. J Geol. 1928;36:458-70.

161. Blom H, Märss T, Miller CG. Silurian and earliest Devonian birkeniid anaspids from the Northern Hemisphere. Trans R Soc Edinb-Earth Sci. 2002;92:263-323.

162. Vladykov VD. A female sea lamprey (Petromyzon marinus) with a true anal fin, and the question of the presence of an anal fin in Petromyzonidae. Can J Zool. 1973;51:221-4.

163. Vladykov VD, Kott E. Description and key to metamorphosed specimens and ammocoetes of Petromyzonidae found in the Great Lakes region. Can J Fish Aquat Sci. 1980;37:1616-25.

164. Hume JB, Bean CW, Adams CE. Morphological abnormalities in a population of Lampetra planeri, with a short review of petromyzontid teratologies. J Fish Biol. 2014;84:1614-9.

165. Janvier P. Homologies and evolutionary transitions in early vertebrate history. In: Anderson JS, Sues HD, editors. Major transitions in vertebrate evolution. Bloomington: Indiana University Press; 2007. p. 57-121.

166. Janvier P. Early jawless vertebrates and cyclostome origins. Zool Sci. 2008;25: 1045-56.

167. Janvier $\mathrm{P}$, Lund R. Hardistiella montanensis n. gen. et sp. (Petromyzontida) from the Lower Carboniferous of Montana, with remarks on the affinities of the lampreys. J Vertebr Paleontol. 1983;2:407-13.

168. Bardack D, Zangerl R. First fossil lamprey: a record from the Pennsylvanian of Illinois. Science. 1968;162:1265-7.

169. Forey PL. Yet more reflections on agnathan-gnathostome relationships. J Vertebr Paleontol. 1984;4:330-43.

170. Bardack D. First fossil hagfish (Myxinoidea): a record from the Pennsylvanian of Illinois. Science. 1991;254:701-3.

171. Gess RW, Coates MI, Rubidge BS. A lamprey from the Devonian period of South Africa. Nature. 2006:443:981-4.

172. Morris SC, Caron JB. A primitive fish from the Cambrian of North America. Nature. 2014;512:419-U3.

173. McCoy VE, Saupe EE, Lamsdell JC, Tarhan LG, McMahon S, Lidgard S, Mayer $P$, Whalen $C D$, Soriano C, Finney $L$, et al. The 'Tully monster' is a vertebrate. Nature. 2016:532:496-9.

174. Lund R. Stethacanthid elasmobranch remains from the Bear Gulch Limestone (Namurian E2b) of Montana. Am Mus Novit. 1985;2828:1-24.

175. Gayet M, Meunier FJ, Kirschbaum F. Ellisella kirschbaumi Gayet \& Meunier, 1991, Gymnotiforme fossile de Bolivie et ses relations phylogénétiques au sein des formes actuelles. Cybium. 1994;18:273-306.
176. Albert JS. Species diversity and phylogenetic systematics of American knifefishes (Gymnotiformes, Teleostei). Misc Pub Mus Zool Univ Mich. 2001;190:1-127.

177. Albert JS, Crampton WGR. A new species of electric knifefish, genus Compsaraia (Gymnotiformes: Apteronotidae) from the Amazon River, with extreme sexual dimorphism in snout and jaw length. Syst Biodivers. 2009;7:81-92.

178. Janvier $P$. The phylogeny of the Craniata, with particular reference to the significance of fossil "agnathans". J Vertebr Paleontol. 1981;1:121-59.

179. Janvier P. Norselaspis glacialis n.g., n.sp. et les relations phylogénétiques entre les Kieraspidiens (Osteostraci) du Dévonien inférieur du Spitsberg. Palaeovertebrata. 1981;11:19-131.

180. Janvier P. Environmental framework of the diversification of the Osteostraci during the Silurian and Devonian. Philos Trans R Soc Lond B-Biol Sci. 1985; 309:259-72.

181. Scott BR, Wilson MVH. A new species of Waengsjoeaspis (Cephalaspidomorpha, Osteostraci) from the Early Devonian of northwestern Canada, with a redescription of $W$. nahanniensis and implications for growth, variation, morphology, and phylogeny. J Vertebr Paleontol. 2012;32:1235-53.

182. Young GC. Devonian sharks from south-eastern Australia and Antarctica. Paleontology. 1982;25:817-43.

183. Miller RF, Cloutier R, Turner S. The oldest articulated chondrichthyan from the Early Devonian period. Nature. 2003;425:501-4.

184. Hanke GF, Wilson MVH. The putative stem-group chondrichthyans Kathemacanthus and Seretolepis from the Lower Devonian MOTH locality, Mackenzie Mountains, Canada. In: Elliott DK, Maisey JG, Yu X, Miao D, editors. Morphology, phylogeny and paleobiogeography of fossil fishes. Munich: Verlag Dr. Friedrich Pfeil; 2010. p. 159-82.

185. Lund R, Grogan ED. Relationships of the Chimaeriformes and the basal radiation of the Chondrichthyes. Rev Fish Biol Fish. 1997;7:65-123.

186. Lund R, Grogan ED, Fath M. On the relationships of the Petalodontiformes (Chondrichthyes). Paleontol J. 2014;48:1015-29.

187. Grogan ED, Lund R. A basal elasmobranch, Thrinacoselache gracia n. gen. \& sp., (Thrinacodontidae, new family) from the Bear Gulch Limestone, Serpukhovian of Montana, USA. J Vertebr Paleontol. 2008;28:970-88.

188. Schultze H-P. Dipnoans as sarcopterygians. J Morphol. 1986;190:39-74.

189. Zhu M, Zhao WJ, Jia LT, Lu J, Qiao T, Qu QM. The oldest articulated osteichthyan reveals mosaic gnathostome characters. Nature. 2009;458:469-74.

190. Zhu M, Yu XB, Choo B, Qu QM, Jia LT, Zhao WJ, Qiao T, Lu J. Fossil fishes from China provide first evidence of dermal pelvic girdles in osteichthyans. PLOS ONE. 2012;7:e35103.

191. Friedman M. Styloichthys as the oldest coelacanth: implications for early osteichthyan interrelationships. J Syst Palaeontol. 2007;5:289-343.

192. Brazeau MD, de Winter V. The hyoid arch and braincase anatomy of Acanthodes support chondrichthyan affinity of 'acanthodians'. Proc R Soc BBiol Sci. 2015;282:6.

193. Lu J, Giles S, Friedman M, den Blaauwen JL, Zhu M. The oldest actinopterygian highlights the cryptic early history of the hyperdiverse rayfinned fishes. Curr Biol. 2016;26:1-7.

194. Taverne L. Osorioichthys marginis, "Paléonisciforme" du Famennien de Belgique, et la phylogénie des actinoptérygiens dévoniens (Pisces). Bull Inst Roy Sci Nat Belgique. 1997;67:57-78.

195. Zhu M, Schultze H-P. Interrelationships of basal osteichthyans. In: Ahlberg PE, editor. Major events in early vertebrate evolution: palaeontology, phylogeny, genetics and development. London: Taylor \& Francis; 2001. p. 289-314.

196. Zhu M, Yu XB, Wang W, Zhao WJ, Jia LT. A primitive fish provides key characters bearing on deep osteichthyan phylogeny. Nature. 2006;441:77-80.

197. Giles S, Darras L, Clément G, Blieck A, Friedman M. An exceptionally preserved Late Devonian actinopterygian provides a new model for primitive cranial anatomy in ray-finned fishes. Proc R Soc B-Biol Sci. 2015;282:10.

198. Jayaram KC. The freshwater fishes of India, Pakistan, Bangladesh, Burma and Sri Lanka. Calcutta: Zoological Survey of India; 1981.

199. Jayaram KC. Aid to the identification of the siluroid fishes of India, Burma, Sri Lanka, Pakistan and Bangladesh. 5. Ariidae and Plotosidae. Records of the Zoological Survey of India Miscellaneous publications. 1982;Occas. Pap. 37:1-41.

200. Ferraris C. Plotosidae. In: Carpenter KE, Niem VH, editors. FAO species identification guide for fishery purposes. The living marine ressources of the western Central Pacific, Volume 3, Batoid fishes, chimaeras and bony fishes part 1 (Elopidae to Linophrynidae). Rome: Food and Agriculture Organization of the United Nations; 1999. p. 1880-3.

201. Johnson GD, Patterson C. Percomorph phylogeny: a survey of acanthomorphs and a new proposal. Bull Mar Sci. 1993;52:554-626. 
202. Sandon H. An abnormal specimen of Synodontis membranaceus (Teleostei, Siluroidea), with a discussion on the evolutionary history of the adipose fin in fish. Proc Zool Soc Lond. 1956;127:453-9.

203. Davesne D, Friedman M, Barriel V, Lecointre G, Janvier P, Gallut C, Otero O. Early fossils illuminate character evolution and interrelationships of Lampridiformes (Teleostei, Acanthomorpha). Zool J Linn Soc. 2014;172:475-98.

204. Delbarre DJ, Davesne D, Friedman M. Anatomy and relationships of Aipichthys pretiosus and 'Aipichthys' nuchalis (Acanthomorpha: Lampridomorpha), with a review of Late Cretaceous relatives of oarfishes and their allies. J Syst Palaeontol. 2015;14:545-67.

205. Otero O. A new genus Aipichthyoidea (Teleostei, Acanthomorpha) from the Lower Cenomanian of Hgula (Lebanon): description and phylogenetic relationships. Comptes Rendus Acad Sci Ser II-A. 1997;325:453-8.

206. Otero O, Gayet M. Anatomy and phylogeny of the Aipichthyoidea nov. of the Cenomanian Tethys and their place in the Acanthomorpha (Teleostei). Neues Jahrb Geol P-A. 1996;202:313-44.

207. Murray AM, Wilson MVH. Four new basal acanthomorph fishes from the Late Cretaceous of Morocco. J Vertebr Paleontol. 2014;34:34-48.

208. Richardson LR. Neomyxine n.g. (Cyclostomata) based on Myxine biniplicata Richardson and Jowett 1951, and further data on the species. T Roy Soc NZ. 1953:81:379-83.

209. Richardson LR. A new genus and species of Myxinidae. T Roy Soc NZ. 1958; 85:283-7.

210. Zintzen $V$, Roberts $C D$, Shepherd L, Stewart AL, Struthers CD, Anderson MJ, McVeagh M, Noren M, Fernholm B. Review and phylogeny of the New Zealand hagfishes (Myxiniformes: Myxinidae), with a description of three new species. Zool J Linn Soc. 2015;174:363-93.

211. Janvier $P$. Les nageoires paires des ostéostracés et la position systématique des céphalaspidomorphes. Ann Paléontol (Vert). 1978;64:113-42.

212. Zug G. The endoskeleton: The comparative anatomy of the girdles, the sternum, and the paired appendages. In: Wake MH, editor. Hyman's comparative vertebrate anatomy. 3rd ed. Chicago: The University of Chicago Press; 1979. p. 238-64.

213. Goodrich ES. Notes on the development, structure, and origin of the median and paired fins of fish. Q J Microsc Sci. 1906;50:333-76.

214. Schubert M, Holland LZ, Holland ND. Characterization of an amphioxus Wnt gene, AmphiWnt11, with possible roles in myogenesis and tail outgrowth. Genesis. 2000;27:1-5.

215. Denison RH. Evolution and classification of the Osteostraci. Fieldiana Geol. 1951;11:157-96.

216. Young GC. The first armoured agnathan vertebrates from the Devonian of Australia. In: Chang M-M, Liu Y-H, Zhang G-R, editors. Early vertebrates and related problems of evolutionary biology. Beijing: Science Press; 1991. p. 67-85.

217. Wilson MVH, Märss T. Anatomy of the Silurian thelodont Phlebolepis elegans Pander. Est J Earth Sci. 2012;61:261-76.

218. Gross W. Neuuntersuchung des Stensiöellida (Arthrodira, Unterdevon). Notizbl hess Landesamt Bodenforsch. 1962;90:48-86.

219. Grünbaum T, Cloutier R, Vincent B. Dynamic skeletogenesis in fishes: insight of exercise training on developmental plasticity. Dev Dyn. 2012;241:1507-24.

220. Johanson Z, Ericsson R, Long J, Evans F, Joss J. Development of the axia skeleton and median fin in the Australian lungfish, Neoceratodus forsteri. Open Zool J. 2009;2:91-101.

221. Cloutier R, Caron A, Grünbaum T, Le François NR. Effect of water velocity on the timing of skeletogenesis in the Arctic charr, Salvelinus alpinus (Salmoniformes: Teleostei): an empirical case of developmental plasticity. Int J Zool. 2010;2010:1-15

222. Larouche $\mathrm{O}$, Cloutier R, Zelditch ML. Head, body and fins: patterns of morphological integration and modularity in fishes. Evol Biol. 2015;42:296-311.

223. Crotwell PL, Sommervold AR, Mabee PM. Expression of bmp2a and bmp2b in late-stage zebrafish median fin development. Gene Expr Patterns. 2004;5:291-6.

224. Ruvinsky I, Gibson-Brown JJ. Genetic and developmental bases of serial homology in vertebrate limb evolution. Development. 2000;127:5233-44.

225. Tanaka M, Onimaru K. Acquisition of the paired fins: a view from the sequential evolution of the lateral plate mesoderm. Evol Dev. 2012;14:412-20.

226. Hanke GF, Wilson MVH. Anatomy of the Early Devonian acanthodian Brochoadmones milesi based on nearly complete body fossils, with comments on the evolution and development of paired fins. J Vertebr Paleontol. 2006;26:526-37.

227. Holland ND, Chen JY. Origin and early evolution of the vertebrates: new insights from advances in molecular biology, anatomy, and palaeontology. Bioessays. 2001;23:142-51.
228. Sansom IJ, Donoghue PCJ, Albanesi G. Histology and affinity of the earliest armoured vertebrate. Biol Lett. 2005;1:446-9.

229. Wilson MVH, Märss T. Theolodont phylogeny revisited, with inclusion of key scale-based taxa. Est J Earth Sci. 2009;58:297-310.

230. Blom H. New birkeniid anaspid from the Lower Devonian of Scotland and its phylogenetic implications. Paleontology. 2012;55:641-52.

231. Wilson MVH, Märss T. Toward a phylogeny of the thelodonts. In: Arratia G, Wilson MVH, Cloutier R, editors. Recent advances in the origin and early radiation of vertebrates. Munich: Verlag Dr. Friedrich Pfeil; 2004. p. 95-108.

232. Forey PL, Gardiner BG. Observations on Ctenurella (Ptyctodontida) and the classification of placoderm fishes. Zool J Linn Soc. 1986;86:43-74.

233. Hanke GF, Wilson MVH. New teleostome fishes and acanthodian systematics. In: Arratia G, Wilson MVH, Cloutier R, editors. Recent advances in the origin and early radiation of vertebrates. Munich: Verlag Dr. Friedrich Pfeil; 2004. p. 189-216.

234. Carr RK, Johanson Z, Ritchie A. The phyllolepid placoderm Cowralepis mclachlani: insights into the evolution of feeding mechanisms in jawed vertebrates. J Morphol. 2009;270:775-804.

235. Burrow CJ, Turner S. Reassessment of "Protodus" scoticus from the Early Devonian of Scotland. In: Elliott DK, Maisey JG, Yu X, Miao D, editors. Morphology, phylogeny and paleobiogeography of fossil fishes. Munich: Verlag Dr. Friedrich Pfeil; 2010. p. 123-44.

236. Hanke GF, Davis SR. A re-examination of Lupopsyrus pygmaeus Bernacsek \& Dineley, 1977 (Pisces, Acanthodii). Geodiversitas. 2012;34:469-87.

237. Giles S, Coates MI, Garwood RJ, Brazeau MD, Atwood R, Johanson Z, Friedman M. Endoskeletal structure in Cheirolepis (Osteichthyes, Actinopterygii), an early ray-finned fish. Paleontology. 2015;58:849-70.

238. Dunn KA, Morrissey JF. Molecular phylogeny of elasmobranchs. Copeia. 1995;1995:526-31.

239. de Carvalho MR, Maisey JG. Phylogenetic relationships of the Late Jurassic shark Protospinax Woodward 1919 (Chondrichthyes: Elasmobranchii). In: Arratia G, Viohl G, editors. Mesozoïc fishes — systematics and paleoecology. Munich: Verlag Dr. Friedrich Pfeil; 1996. p. 9-46.

240. Kitamura T, Takemura A, Watabe S, Taniuchi T, Shimizu M. Molecular phylogeny of the sharks and rays of superorder Squalea based on mitochondrial cytochrome b gene. Fish Sci. 1996;62:340-3.

241. Shirai S. Phylogenetic interrelationships of neoselachians (Chondrichthyes, Euselachii). In: Stiassny ML, Parenti LR, Johnson GD, editors. Interrelationships of fishes. San Diego: Academic Press; 1996. p. 9-34.

242. Grogan ED, Lund R. Debeerius ellefseni (fam. nov., gen. nov., spec. nov.), an autodiastylic chondrichthyan from the Mississippian Bear Gulch Limestone of Montana (USA), the relationships of the chondrichthyes, and comments on gnathostome evolution. J Morphol. 2000;243:219-45.

243. Coates MI, Sequeira SEK. A new stethacanthid chondrichthyan from the Lower Carboniferous of Bearsden, Scotland. J Vertebr Paleontol. 2001;21:438-59.

244. Sequeira SEK, Coates MI. Reassessment of 'Cladodus' neilsoni Traquair: a primitive shark from the Lower Carboniferous of East Kilbride, Scotland. Paleontology. 2000;43:153-72.

245. Douady CJ, Dosay M, Shivji MS, Stanhope MJ. Molecular phylogenetic evidence refuting the hypothesis of Batoidea (rays and skates) as derived sharks. Mol Phylogenet Evol. 2003;26:215-21.

246. Grogan ED, Lund R. The origin and relationships of early Chondrichthyes. In: Carrier JC, Musick JA, Heithaus MR, editors. Biology of sharks and their relatives. Boca Raton: CRC Press; 2004. p. 3-31.

247. Winchell CJ, Martin AP, Mallatt J. Phylogeny of elasmobranchs based on LSU and SSU ribosomal RNA genes. Mol Phylogenet Evol. 2004;31:214-24.

248. Naylor GJP, Ryburn JA, Fedrigo O, Lopez A. Phylogenetic relationships among the major lineages of modern elasmobranchs. In: Hamlett WC, editor. Reproductive biology and phylogeny of Chondrichthyes: sharks, batoids, and chimaeras. Enfield: Science Publishers; 2005. p. 1-25.

249. Dosay-Akbulut M. Specification of phylogenetic interrelations between skate-rays and sharks. J Evol Biochem Physiol. 2006;42:128-33.

250. Human BA, Owen EP, Compagno LJV, Harley EH. Testing morphologically based phylogenetic theories within the cartilaginous fishes with molecular data, with special reference to the catshark family (Chondrichthyes; Scyliorhinidae) and the interrelationships within them. Mol Phylogenet Evol. 2006;39:384-91.

251. Inoue JG, Miya M, Lam K, Tay BH, Danks JA, Bell J, Walker TI, Venkatesh B. Evolutionary origin and phylogeny of the modern holocephalans (Chondrichthyes: Chimaeriformes): a mitogenomic perspective. Mol Biol Evol. 2010;27:2576-86. 
252. Klug S. Monophyly, phylogeny and systematic position of the †Synechodontiformes (Chondrichthyes, Neoselachii). Zool Scr. 2010;39: $37-49$.

253. Vélez-Zuazo X, Agnarsson I. Shark tales: a molecular species-level phylogeny of sharks (Selachimorpha, Chondrichthyes). Mol Phylogenet Evol. 2011;58:207-17.

254. Aschliman NC, Nishida M, Miya M, Inoue JG, Rosana KM, Naylor GJP. Body plan convergence in the evolution of skates and rays (Chondrichthyes: Batoidea). Mol Phylogenet Evol. 2012;63:28-42.

255. Li CH, Matthes-Rosana KA, Garcia M, Naylor GJP. Phylogenetics of Chondrichthyes and the problem of rooting phylogenies with distant outgroups. Mol Phylogenet Evol. 2012;63:365-73.

256. Aschliman NC, Claeson KM, McEachran JD. Phylogeny of Batoidea. In: Carrier JC, Musick JA, Heithaus MR, editors. Biology of sharks and their relatives. 2nd ed. Boca Raton: CRC Press; 2012. p. 57-95.

257. Naylor GJP, Caira JN, Jensen K, Rosana KAM, Straube N, Lakner C. Elasmobranch phylogeny: a mitochondrial estimate based on 595 species. In: Carrier JC, Musick JA, Heithaus MR, editors. Biology of sharks and their relatives. 2nd ed. Boca Raton: CRC Press; 2012. p. 31-56.

258. Pavan-Kumar A, Gireesh-Babu P, Babu PPS, Jaiswar AK, Krishna V, Prasasd KP, Chaudhari A, Raje SG, Chakraborty SK, Krishna G, et al. Molecular phylogeny of elasmobranchs inferred from mitochondrial and nuclear markers. Mol Bio Rep. 2014;41:447-57.

259. Gardiner BG, Schaeffer B. Interrelationships of lower actinopterygian fishes. Zool J Linn Soc. 1989;97:135-87.

260. Le HLV, Lecointre G, Perasso R. A 28S rRNA-based phylogeny of the gnathostomes: first steps in the analysis of conflict and congruence with morphologically based cladograms. Mol Phylogenet Evol. 1993;2:31-51.

261. Grande L, Bemis WE. A comprehensive phylogenetic study of amiid fishes (Amiidae) based on comparative skeletal anatomy. An empirical search for interconnected patterns of natural history. J Vertebr Paleontol Suppl. 1998; 18:1-696.

262. Arratia G. The monophyly of Teleostei and stem-group teleosts. Consensus and disagreements. In: Arratia G, Schultze H-P, editors. Mesozoic fishes 2 systematics and fossil record. Munich: Verlag Dr. Friedrich Pfeil; 1999. p. 265-334.

263. Coates Ml. Endocranial preservation of a Carboniferous actinopterygian from Lancashire, UK, and the interrelationships of primitive actinopterygians. Philos Trans R Soc Lond B-Biol Sci. 1999;354:435-62.

264. Arratia G. New teleostean fishes from the Jurassic of southern Germany and the systematic problems concerning the 'pholidophoriforms'. Paläont Z. 2000;74:113-43.

265. Wiley EO, Johnson GD, Dimmick WW. The interrelationships of acanthomorph fishes: a total evidence approach using molecular and morphological data. Biochem Syst Ecol. 2000;28:319-50.

266. Filleul A, Lavoué S. Basal teleosts and the question of elopomorph monophyly. Morphological and molecular approaches. Comptes Rendus Acad Sci Ser III-Sci Vie. 2001;324:393-9.

267. Inoue JG, Kumazawa Y, Miya M, Nishida M. The historical biogeography of the freshwater knifefishes using mitogenomic approaches: a Mesozoic origin of the Asian notopterids (Actinopterygii: Osteoglossomorpha). Mol Phylogenet Evol. 2009:51:486-99.

268. Inoue JG, Miya M, Tsukamoto K, Nishida M. A mitogenomic perspective on the basal teleostean phylogeny: resolving higher-level relationships with longer DNA sequences. Mol Phylogenet Evol. 2001;20:275-85.

269. Inoue JG, Miya M, Tsukamoto K, Nishida M. Basal actinopterygian relationships: a mitogenomic perspective on the phylogeny of the "ancient fish". Mol Phylogenet Evol. 2003;26:110-20.

270. Inoue JG, Miya M, Tsukamoto K, Nishida M. Mitogenomic evidence for the monophyly of elopomorph fishes (Teleostei) and the evolutionary origin of the leptocephalus larva. Mol Phylogenet Evol. 2004;32:274-86.

271. Gardiner BG, Schaeffer B, Masserie JA. A review of the lower actinopterygian phylogeny. Zool J Linn Soc. 2005;144:511-25.

272. Ishiguro NB, Miya M, Nishida M. Basal euteleostean relationships: a mitogenomic perspective on the phylogenetic reality of the "Protacanthopterygii". Mol Phylogenet Evol. 2003;27:476-88.

273. Saitoh K, Miya M, Inoue JG, Ishiguro NB, Nishida M. Mitochondrial genomics of ostariophysan fishes: perspectives on phylogeny and biogeography. J Mol Evol. 2003;56:464-72

274. Miya M, Satoh TR, Nishida M. The phylogenetic position of toadfishes (order Batrachoidiformes) in the higher ray-finned fish as inferred from partitioned Bayesian analysis of 102 whole mitochondrial genome sequences. Biol J Linnean Soc. 2005:85:289-306.
275. Cavin L. Diversity of Mesozoic semionotiform fishes and the origin of gars (Lepisosteidae). Naturwissenschaften. 2010;97:1035-40.

276. Lavoué S, Miya M, Inoue JG, Saitoh K, Ishiguro NB, Nishida M. Molecular systematics of the gonorynchiform fishes (Teleostei) based on whole mitogenome sequences: implications for higher-level relationships within the Otocephala. Mol Phylogenet Evol. 2005;37:165-77.

277. Cavin L, Suteethorn V. A new Semionotiform (Actinopterygii, Neopterygii) from Upper Jurassic Lower Cretaceous deposits of north-east Thailand, with comments on the relationships of semionotiforms. Paleontology. 2006;49:339-53.

278. Hurley IA, Mueller RL, Dunn KA, Schmidt EJ, Friedman M, Ho RK, Prince VE, Yang $\mathrm{ZH}$, Thomas MG, Coates MI. A new time-scale for ray-finned fish evolution. Proc R Soc B-Biol Sci. 2007;274:489-98.

279. Arratia G. The varasichthyid and other crossognathiform fishes, and the Break-up of Pangaea. In: Cavin L, Longbottom A, Richter M, editors. Fishes and the break-up of Pangaea, vol. 295. London: The Geological Society of London Special Publication; 2008. p. 71-92.

280. Kawahara R, Miya M, Mabuchi K, Lavoué S, Inoue JG, Satoh TP, Kawaguchi A, Nishida M. Interrelationships of the 11 gasterosteiform families (sticklebacks, pipefishes, and their relatives): a new perspective based on whole mitogenome sequences from 75 higher teleosts. Mol Phylogenet Evol. 2008;46:224-36.

281. Setiamarga DHE, Miya M, Yamanoue Y, Mabuchi K, Satoh TP, Inoue JG, Nishida M. Interrelationships of Atherinomorpha (medakas, flyingfishes, killifishes, silversides, and their relatives): the first evidence based on whole mitogenome sequences. Mol Phylogenet Evol. 2008;49:598-605.

282. Li B, Dettai A, Cruaud C, Couloux A, Desoutter-Meniger M, Lecointre G. RNF213, a new nuclear marker for acanthomorph phylogeny. Mol Phylogenet Evol. 2009;50:345-63.

283. López-Arbarello A. Phylogenetic interrelationships of ginglymodian fishes (Actinopterygii: Neopterygii). PLOS ONE. 2012;7:e33997.

284. Near TJ, Eytan RI, Dornburg A, Kuhn KL, Moore JA, Davis MP, Wainwright PC, Friedman M, Smith WL. Resolution of ray-finned fish phylogeny and timing of diversification. Proc Natl Acad Sci U S A. 2012;109:13698-703.

285. Faircloth BC, Sorenson L, Santini F, Alfaro ME. A phylogenomic perspective on the radiation of ray-finned fishes based upon targeted sequencing of ultraconserved elements (UCES). PLoS ONE. 2013;8:e65923.

286. Betancur-R R, Broughton RE, Wiley EO, Carpenter K, López JA, Li C, Holcroft $\mathrm{NI}$, Arcila D, Sanciangco M, Cureton JC, et al. The tree of life and a new classification of bony fishes. PLoS Currents Tree of Life. 2013:1-41. doi: 10 1371/currents.tol.53ba26640df0ccaee75bb165c8c26288.

287. Broughton RE, Betancur-R R, Li C, Arratia G, Ortí G. Multi-locus phylogenetic analysis reveals the pattern and tempo of bony fish evolution. PLoS Currents Tree of Life. 2013:1-33. doi:10.1371/currents.tol. 2ca8041495ffafd0c92756e75247483e.

288. Miya M, Friedman M, Satoh TP, Takeshima H, Sado T, Iwasaki W, Yamanoue Y, Nakatani M, Mabuchi K, Inoue JG, et al. Evolutionary origin of the Scombridae (tunas and mackerels): members of a Paleogene adaptive radiation with 14 other pelagic fish families. PLOS ONE. 2013:8:e73535.

289. Near TJ, Dornburg A, Eytan RI, Keck BP, Smith WL, Kuhn KL, Moore JA, Price $\mathrm{SA}$, Burbrink FT, Friedman M, et al. Phylogeny and tempo of diversification in the superradiation of spiny-rayed fishes. Proc Natl Acad Sci U S A. 2013; 110:12738-43.

290. Dornburg A, Townsend JP, Friedman M, Near TJ. Phylogenetic informativeness reconciles ray-finned fish molecular divergence times. BMC Evol Biol. 2014;14:14

291. Arratia G. New remarkable Late Jurassic teleosts from southern Germany: Ascalaboidae n. fam., its content, morphology, and phylogenetic relationships. Foss Rec. 2016;19:31-59.

292. Eytan Rl, Evans BR, Dornburg A, Lemmon AR, Lemmon EM, Wainwright PC, Near TJ. Are 100 enough? Inferring acanthomorph teleost phylogeny using Anchored Hybrid Enrichment. BMC Evol Biol. 2015;15:20.

293. Xu GH, Zhao LJ, Shen CC. A Middle Triassic thoracopterid from China highlights the evolutionary origin of overwater gliding in early ray-finned fishes. Biol Lett. 2015;11:5.

294. Ahlberg PE. A reexamination of sarcopterygian interrelationships, with special reference to the Porolepiformes. Zool J Linn Soc. 1991;103:241-87.

295. Young GC, Long JA, Ritchie A. Crossopterygian fishes from the Devonian of Antarctica: systematics, relationships and biogeographic significance. Rec Aust Mus. 1992;14(Suppl):1-77.

296. Chang M-M, Yu X. Reexamination of the relationship of Middle Devonian osteolepids - fossil characters and their interpretations. Am Mus Novit. 1997;3189:1-20 
297. Zhu M, Schultze H-P. The oldest sarcopterygian fish. Lethaia. 1997;30:293-304

298. Ahlberg PE, Jonanson Z. Osteolepiforms and the ancestry of tetrapods. Nature. 1998;395:792-4.

299. Zhu M, Yu XB, Janvier P. A primitive fossil fish sheds light on the origin of bony fishes. Nature. 1999;397:607-10.

300. Zhu M, Yu XB, Ahlberg PE. A primitive sarcopterygian fish with an eyestalk. Nature. 2001:410:81-4

301. Johanson Z, Ahlberg PE. Devonian rhizodontids and tristichopterids (Sarcopterygii; Tetrapodomorpha) from East Gondwana. Trans R Soc EdinbEarth Sci. 2001;92:43-74.

302. Zhu M, Yu XB. A primitive fish close to the common ancestor of tetrapods and lungfish. Nature. 2002;418:767-70.

303. Zhu M, Ahlberg PE. The origin of the internal nostril of tetrapods. Nature. 2004;432:94-7.

304. Long JA, Young GC, Holland T, Senden TJ, Fitzgerald EMG. An exceptional Devonian fish from Australia sheds light on tetrapod origins. Nature. 2006; 444:199-202.

305. Friedman M, Coates Ml, Anderson P. First discovery of a primitive coelacanth fin fills a major gap in the evolution of lobed fins and limbs. Evol Dev. 2007;9:329-37.

306. Snitting D. A redescription of the anatomy of the Late Devonian Spodichthys buetleri Jarvik, 1985 (Sarcopterygii, Tetrapodomorpha) from East Greenland. J Vertebr Paleontol. 2008;28:637-55.

307. Holland T, Long JA. On the phylogenetic position of Gogonasus andrewsae Long 1985, within the Tetrapodomorpha. Acta Zool. 2009;90:285-96.

308. Lu J, Zhu M, Long JA, Zhao WJ, Senden TJ, Jia LT, Qiao T. The earliest known stem-tetrapod from the Lower Devonian of China. Nat Comm. 2012;3:7.

309. Lu J, Zhu M, Ahlberg PE, Qiao T, Zhu Y, Zhao W, Jia L. A Devonian predatory fish provides insights into the early evolution of modern sarcopterygians. Sci Adv. 2016;2:e1600154.

310. Swartz B. A marine stem-tetrapod from the Devonian of western North America. PLoS ONE. 2012;7:e33683.

311. Aldridge RJ. Conodont palaeobiology: a historical review. In: Aldridge RJ, editor. Palaobiology of conodonts. Chichester: Ellis Horwood Ltd.; 1987. p. 11-34.

312. Aldridge RJ, Briggs DEG. Sweet talk. Paleobiology. 1990;16:241-6.

313. Aldridge RJ, Briggs DEG, Clarkson ENK, Smith MP. The affinities of conodonts - new evidence from the Carboniferous of Edinburgh, Scotland. Lethaia. 1986;19:279-91.

314. Pridmore PA, Barwick RE, Nicoll RS. Soft anatomy and the affinities of conodonts. Lethaia. 1997;29:317-28

315. Blieck A, Turner S, Burrow CJ, Schultze H-P, Rexroad CB, Bultynck P, Nowlan GS. Fossils, histology, and phylogeny: why conodonts are not vertebrates. Episodes. 2010;33:234-41

316. Briggs DEG. A major extinct group added to the vertebrates. Science. 1992; 256:1285-6.

317. Aldridge RJ, Theron JN. Conodonts with preserved soft tissue from a new Ordovician Konservat-Lagerstätte. J Micropaleontol. 1993;12:113-7.

318. Briggs DEG, Kear AJ. Decay of Branchiostoma — implications for soft-tissue preservation in conodonts and other primitive chordates. Lethaia. 1994;26:275-87.

319. Gabbott SE, Aldridge RJ, Theron JN. A giant conodont with preserved muscle tissue from the Upper Ordovician of South Africa. Nature. 1995;374: 800-3.

320. Purnell MA. Microwear on conodont elements and macrophagy in the first vertebrates. Nature. 1995;374:798-800.

321. Aldridge RJ, Purnell MA. The conodont controversies. Trends Ecol Evol. 1996; 11:463-8.

322. Donoghue PCJ, Purnell MA, Aldridge RJ. Conodont anatomy, chordate phylogeny and vertebrate classification. Lethaia. 1998;31:211-9.

323. Sweet WC, Donoghue PCJ. Conodonts: past, present, future. J Paleontol. 2001;75:1174-84

324. Schubert M, Escriva H, Xavier-Neto J, Laudet V. Amphioxus and tunicates as evolutionary model systems. Trends Ecol Evol. 2006;21:269-77.

325. Sansom IJ, Smith MP, Armstrong HA, Smith MM. Presence of the earliest vertebrate hard tissues in conodonts. Science. 1992;256:1308-11.

326. Sansom IJ, Smith MP, Smith MM. Dentine in conodonts. Nature. 1994;368:591.

327. Smith MM, Sansom IJ, Smith MP. Teeth' before armour: the earliest vertebrate mineralized tissues. Mod Geol. 1996;20:303-19.

328. Kemp A, Nicoll RS. A histochemical analysis of biological residues in conodont elements. Mod Geol. 1996;20:287-302.

329. Kemp A, Nicoll RS. Protochordate affinities of conodonts. Cour Forsch Senck. 1995; 182:235-45
330. Kemp A. Hyaline tissue of thermally unaltered conodont elements and the enamel of vertebrates. Alcheringa. 2002;26:23-36.

331. Kemp A. Amino acid residues in conodont elements. J Paleontol. 2002;76: 518-28.

332. Reif W-E. Conodonts, odontodes, stem-groups, and the ancestry of enamel genes. Neues Jahrb Geol P-A. 2006:241:405-39.

333. Schultze H-P. Conodont histology: an indicator of vertebrate relationship? Mod Geol. 1996;20:275-85.

334. Janvier P. Vertebrate characters and the Cambrian vertebrates. C R Palevol. 2003;2:523-31.

335. Shimeld SM, Donoghue PCJ. Evolutionary crossroads in developmental biology: Cyclostomes (lamprey and hagfish). Development. 2012;139:2091-9.

336. Duméril AMC. Zoologie analytique, ou méthode naturelle de classification des animaux. Paris: Imprimerie de H. L. Perronneau; 1806.

337. Schaeffer $B$, Thomson KS. Reflections on agnathan-gnathostome relationships. In: Jacobs LL, editor. Aspects of vertebrate history. Flagstaff: Museum of Northern Arizona Press; 1980. p. 19-33.

338. Løvtrup S. The phylogeny of vertebrata. London: Wiley; 1977.

339. Dingerkus G. Chordate cytogenetic studies: an analysis of their phylogenetic implications with particular reference to fishes and the living coelacanth. Occas Pap Calif Acad Sci. 1979;134:111-27.

340. Janvier P, Blieck A. New data on the internal anatomy of the Heterostraci (Agnatha), with general remarks on the phylogeny of the Craniota. Zool Scr. 1979;8:287-96.

341. Hardisty MW. Biology of the cyclostomes. London: Chapman and Hall; 1979.

342. Jefferies RPS. The ancestry of the vertebrates. Cambridge: Cambridge University Press; 1986.

343. Yalden DW. Feeding mechanisms as evidence for cyclostome monophyly. Zool J Linn Soc. 1985;84:291-300.

344. Stock DW, Whitt GS. Evidence from 18 S ribosomal RNA sequences that lampreys and hagfishes form a natural group. Science. 1992;257:787-9.

345. Mallatt J, Sullivan J. 28 S and 18S rDNA sequences support the monophyly of lampreys and hagfishes. Mol Biol Evol. 1998;15:1706-18.

346. Hedges SB. Molecular evidence for the early history of living vertebrates. In: Ahlberg PE, editor. Major events in early vertebrate evolution: palaeontology, phylogeny, genetics and development. London: Taylor \& Francis; 2001. p. 119-34.

347. Mallatt J, Sullivan J, Winchell CJ. The relationship of lampreys to hagfishes: a spectral analysis of ribosomal DNA sequences. In: Ahlberg PE, editor. Major events in early vertebrate evolution: palaeontology, phylogeny, genetics and development. London: Taylor \& Francis; 2001. p. 106-18.

348. Delarbre C, Gallut C, Barriel V, Janvier P, Gachelin G. Complete mitochondrial DNA of the hagfish, Eptatretus burgeri: the comparative analysis of mitochondrial DNA sequences strongly supports the cyclostome monophyly. Mol Phylogenet Evol. 2002;22:184-92

349. Heimberg AM, Cowper-Sallari R, Semon M, Donoghue PCJ, Peterson KJ. microRNAs reveal the interrelationships of hagfish, lampreys, and gnathostomes and the nature of the ancestral vertebrate. Proc Natl Acad Sci U S A. 2010:107:19379-83.

350. Khonsari RH, Li B, Vernier P, Northcutt RG, Janvier P. Agnathan brain anatomy and craniate phylogeny. Acta Zool. 2009;90:52-68.

351. Miyashita T. Comparative analysis of the anatomy of the Myxinoidea and the ancestry of early vertebrate lineages. M.Sc. Thesis. Edmonton: University of Alberta; 2012

352. Abou Chakra M, Hall BK, Stone JR. Using information in taxonomists' heads to resolve hagfish and lamprey relationships and recapitulate craniatevertebrate phylogenetic history. Hist Biol. 2014;26:652-60.

353. Schaeffer B, Williams M. Relationships of fossil and living elasmobranchs. Am Zool. 1977;17:293-302

354. Goujet D, Young GC. Placoderm anatomy and phylogeny: new insights. In: Arratia G, Wilson MVH, Cloutier R, editors. Recent advances in the origin and early radiation of vertebrates. Munich: Verlag Dr. Friedrich Pfeil; 2004. p. 109-26.

355. Moy-Thomas JA, Miles RS. Palaeozoic fishes. 2nd ed. Philadelphia: W. B. Saunders Company; 1971.

356. Denison RH. Handbook of paleoichthyology, Volume 5, Acanthodii. Stuttgart: Gustav Fischer Verlag; 1979.

357. Goujet D, Young GC. Interrelationships of placoderms revisited. Geobios. 1995;M.S. 19:89-95.

358. Brazeau MD, Friedman M. The origin and early phylogenetic history of jawed vertebrates. Nature. 2015;520:490-7. 
359. Young GC. The relationships of antiarchs (Devonian placoderm fishes) evidence supporting placoderm monophyly. J Vertebr Paleontol. 2008;28:626-36.

360. Shirai S. Phylogenetic relationships of the angel sharks, with comments on elasmobranch phylogeny (Chondrichthyes, Squatinidae). Copeia. 1992;1992: 505-18.

361. de Carvalho MR. Higher-level elasmobranch phylogeny, basal squaleans, and paraphyly. In: Stiassny MLJ, Parenti LR, Johnson GD, editors. Interrelationships of fishes. San Diego: Academic Press; 1996. p. 35-62.

362. Compagno LV. Relationships of living sharks and rays. Am Zool. 1977;17:303-22.

363. Compagno LJV. Interrelationships of living elasmobranchs. Zool J Linn Soc. 1973;53:15-61

Submit your next manuscript to BioMed Central and we will help you at every step:

- We accept pre-submission inquiries

- Our selector tool helps you to find the most relevant journal

- We provide round the clock customer support

- Convenient online submission

- Thorough peer review

- Inclusion in PubMed and all major indexing services

- Maximum visibility for your research

Submit your manuscript at www.biomedcentral.com/submit 